\title{
Inhibitory effects of terrein on lung cancer cell metastasis and angiogenesis
}

\author{
PAIWAN BUACHAN ${ }^{1}$, MANEEKARN NAMSA-AID ${ }^{2}$, HYE KYOUNG SUNG $^{3}$, \\ CHUN PENG $^{3}$, GARY SWEENEY ${ }^{3}$ and WANLAYA TANECHPONGTAMB ${ }^{1}$ \\ ${ }^{1}$ Department of Biochemistry, Faculty of Medicine; ${ }^{2}$ Department of Chemistry, Faculty of Science, \\ Srinakharinwirot University, Bangkok 10110, Thailand; ${ }^{3}$ Department of Biology, \\ York University, Toronto, Ontario M3J 1P3, Canada
}

Received October 28, 2020; Accepted March 1, 2021

DOI: $10.3892 /$ or.2021.8045

\begin{abstract}
Cancer metastasis is the leading cause of mortality in cancer patients. Over $70 \%$ of lung cancer patients are diagnosed at advanced or metastatic stages, and this results in an increased incidence of mortality. Terrein is a secondary bioactive fungal metabolite isolated from Aspergillus terreus. Numerous studies have demonstrated that terrein has anticancer properties, but in the present study, the cellular mechanisms underlying the inhibition of lung cancer cell metastasis by terrein was investigated for the first time. Using MTT assays, the cytotoxic effects of terrein were first examined in human lung cancer cells (A549 cells) and then compared with its cytotoxic effects in three noncancer control cell lines (Vero kidney, L6 skeletal muscle and H9C2 cardiomyoblast cells). The results indicated that terrein significantly reduced the viability of all these cells but exhibited a different level of toxicity in each cell type; these results revealed a specific concentration range in which the effect of terrein was specific to A549 cells. This significant cytotoxic effect of terrein in A549 cells was verified using LDH assays. It was then demonstrated that terrein attenuated the proliferation of A549 cells using IncuCyte image analysis. Regarding its antimetastatic effects, terrein significantly inhibited A549 cell adhesion, migration and invasion. In addition, terrein suppressed the angiogenic processes of A549 cells, including vascular endothelial growth factor (VEGF) secretion, capillary-like tube formation and VEGF/VEGFR2 interaction. These phenomena were accompanied by reduced protein levels of integrins, FAK, and their downstream mediators (e.g., PI3K, AKT, mTORC1 and P70S6K). All these data indicated that terrein was able
\end{abstract}

Correspondence to: Dr Wanlaya Tanechpongtamb, Department of Biochemistry, Faculty of Medicine, Srinakharinwirot University, Sukhumvit 23, Bangkok 10110, Thailand

E-mail:wanlaya@g.swu.ac.th

Key words: terrein, non-small cell lung cancer, migration, invasion, angiogenesis, metastasis to inhibit all the major metastatic processes in human lung cancer cells, which is crucial for cancer treatment.

\section{Introduction}

Lung cancer is a disease that is characterized by uncontrolled growth of abnormal cells in one or both of the lungs. Lung cancer is a common type of cancer that has been identified as the leading cause of cancer-related deaths worldwide. The data from GLOBOCAN 2018, a project of the International Agency for Research on Cancer (IARC), estimated that lung cancer caused 1.8 million deaths, resulting in a mortality rate of $18.4 \%$; thus, lung cancer ranks first in mortality among all cancer types. In Thailand, 23,957 (15.1\%) new lung cancer cases and 21,371 (20.1\%) lung cancer-related deaths were reported; thus, lung cancer ranks second after liver cancer (1). The high mortality rate results from the late diagnosis of patients already in advanced or metastatic stages (2). Therefore, studying and understanding the molecular mechanisms underlying lung cancer metastasis are essential for the development of therapeutic strategies for lung cancer.

Cancer metastasis is a complex process in which cancer cells spread from a primary tumor site to distant sites. Metastasis includes several processes, including cell proliferation, adhesion, invasion, migration and angiogenesis (3). These processes involve the complex interactions of multiple crucial proteins and signaling pathways that lead to cancer cell movement and survival. Cancer metastasis is typically initiated by the attachment of cancer cells to extracellular matrix (ECM) proteins and then by the activation of integrins (4). Integrin activation contributes to the formation of focal adhesions (FAs) and the stimulation of signaling transduction pathways that regulate cell migration and invasion. FA proteins recruit focal adhesion kinase (FAK) to FAs, and then FAK directly binds to integrins, which subsequently leads to FAK autophosphorylation at Tyr397. FAK is a nonreceptor tyrosine kinase that regulates signaling related to cell adhesion and migration in various cell lines $(5,6)$. For cell migration, FAK activates p85 subunit of phosphatidylinositol 3-kinase (PI3K) (7), which further increases the phosphorylation of the protein kinase-B (AKT) and mammalian target of rapamycin (mTOR) proteins. The involvement of PI3K/AKT/mTOR signaling in cancer 
metastasis has been clearly observed in numerous works through the stimulation of cancer cell development, migration, invasion and motility (8). In addition, phosphorylating ribosomal p70S6 kinase (P70S6K) and eukaryotic translation factor 4E-binding protein 1 (4E-BP1), which are downstream effectors of mTORC1, can also promote cancer cell migration and invasion (9) and cell cycle progression (10).

Angiogenesis is another crucial process that promotes tumor growth and metastasis. This process is activated through the interaction of growth factors and their specific receptors. Vascular endothelial growth factors (VEGFs) are the main regulators of vascular development and angiogenesis initiation. VEGF subtype A (VEGF-A) has been widely studied and plays a major role in angiogenesis by acting through VEGF receptor tyrosine kinase type 2 (VEGFR2) $(11,12)$. VEGFR2 is expressed in different types of cells, such as neuronal cells, megakaryocytes, hematopoietic stem cells and various cancer cells, including lung cancer cells (13-16). The Tyr951, Tyr1175 and Tyr1214 residues of VEGFR2 are the main sites of phosphorylation that stimulate cell migration during angiogenesis. Phosphorylation at Tyr1175 recruits the binding of $\mathrm{SH} 2$ domain-containing adaptor protein $\mathrm{B}$ (SHB), resulting in the activation of FAK and the promotion of actin polymerization, lamellipodia formation and cell migration $(17,18)$.

For lung cancer treatment, standard treatments, such as radiotherapy and chemotherapy, are currently accepted for treating advanced stage lung cancer; however, there are still several issues that need to be considered, such as treatment side effects, drug resistance, and high treatment cost. The development of effective anti-lung cancer agents, especially from natural resources, is a promising approach to increase patient survival. Terrein (4,5-dihydroxy-3-[(E)-1'-propenyl]-2-cyclopenten-1-one, $\left.\mathrm{C}_{8} \mathrm{H}_{10} \mathrm{O}_{3}\right)$ is a natural substance produced by microorganisms. Terrein is a secondary bioactive fungal metabolite that was first isolated from Aspergillus terreus by Raistrick and Smith in 1935 (19). Numerous studies have demonstrated that terrein exerts several potential effects, including anti-inflammation, melanogenesis inhibition and anticancer effects (20-22). Regarding its anticancer effect, terrein was revealed to inhibit cell proliferation through the induction of cell cycle arrest in human hepatoma Bel7402 (23) and human ovarian cancer cells (24). Terrein has also been revealed to induce the apoptosis of ABCG2-expressing breast cancer cells via the caspase-7 pathway and inhibit AKT signaling (25). Additionally, terrein induced apoptosis by regulating p53 and ERK in human cervical carcinoma cells (22). Furthermore, terrein has been revealed to suppress angiogenin production in head and neck cancer cells (26) and androgen-dependent prostate cancer cells (27), and both studies suggested that terrein has an inhibitory effect on angiogenesis. The inhibitory effect of terrein on cell migration has also been observed in human breast cancer cells (28). However, the anticancer effect of terrein on A549 human lung cancer cell metastasis and angiogenesis has not yet been fully elucidated. Therefore, the present study aimed to investigate the inhibitory effects of terrein on human lung cancer cell metastasis and angiogenesis as well as the important cellular mechanisms involved in both processes.

\section{Materials and methods}

Chemicals and reagents. Dulbecco's modified Eagle's medium (DMEM), Eagle's minimum essential medium (EMEM), $\alpha$-minimum essential medium ( $\alpha$-MEM), fetal bovine serum (FBS), $0.25 \%$ trypsin-EDTA, and penicillin-streptomycin were purchased from Gibco/Thermo Fisher Scientific, Inc. 3-(4,5-Dimethylthiazol-2-yl)-2,5 diphenyltetrazolium bromide (MTT) was purchased from USB Corporation. Matrigel was purchased from BD Biosciences. The VEGF-A Human ELISA Kit was purchased from Abcam. The lactate dehydrogenase (LDH) assay was purchased from G-Biosciences.

Cell culture. The A549 human NSCLC cell line (ATCC ${ }^{\circledR}$ CCL-185 ${ }^{\mathrm{TM}}$ ) and normal African green monkey kidney (Vero) cell line (ATCC ${ }^{\circledR}$ CCL-81 ${ }^{\mathrm{TM}}$ ) were purchased from ATCC. The L6 skeletal muscle cell line and H9C2 cardiomyoblast cell line were obtained from author Gary Sweeney, Department of Biology, York University, Toronto, Canada (29,30). The A549 cells and H9C2 cells were maintained in DMEM containing $10 \% \mathrm{FBS}$ and $1 \%$ penicillin/streptomycin. The Vero cells were maintained in EMEM containing $10 \%$ FBS and $1 \%$ penicillin/streptomycin. The L6 cells were maintained in $\alpha$-MEM containing $10 \%$ FBS and $1 \%$ antibiotic-antimycotic. All the cell types were cultured in an incubator at $37^{\circ} \mathrm{C}$ in $5 \% \mathrm{CO}_{2}$ and a $95 \%$ humidified atmosphere. The cells were provided with fresh medium 2 to 3 times per week, and when the cells had grown to approximately $80 \%$ confluence, they were subcultured approximately 2 or 3 times per week.

Preparation of terrein. The fungus Aspergillus terreus CRI301 was cultivated in Sabouraud dextrose agar under stationary conditions at room temperature for 34 days. Then, the Aspergillus terreus CRI301 culture was filtered to separate the cells from the broth. The culture broth was extracted three times with an equal volume of ethyl acetate (EtOAc), and then, the EtOAc layers were combined and evaporated to dryness. The crude EtOAc extract was further purified by Sephadex LH-20 column chromatography (2-cm inner diameter and 125-cm length) and eluted with $\mathrm{MeOH}$. The structure of terrein was characterized by ${ }^{1} \mathrm{H}$ NMR spectroscopy (AVANCE III HD; frequency, $400 \mathrm{MHz}$; TopSpin version 3.6.2 software; Bruker).

Cell viability assay. The cytotoxic effects of terrein in A549 cells and normal cells, including Vero cells, L6 cells and H9C2 cells, was determined using a colorimetric MTT assay. A549, Vero, L6 and H9C2 cells were harvested with $0.25 \%$ trypsin containing $1 \mathrm{mM}$ EDTA, plated in 96-well plates at densities of $1 \times 10^{4}, 1.8 \times 10^{4}, 3 \times 10^{4}$, and $2 \times 10^{4}$ cells/well, respectively, and allowed to adhere overnight. Then, the cells were treated with various concentrations of terrein: $0-1 \mathrm{mM}$ for A549 cells and 0-2 $\mathrm{mM}$ for all the normal cell lines. The highest concentration of dimethyl sulfoxide (DMSO; 0.1\%) was used as the vehicle control. Then, all the plates were incubated for $24 \mathrm{~h}$ at $37^{\circ} \mathrm{C}$. Subsequently, the medium was removed, and $0.5 \mathrm{mg} / \mathrm{ml} \mathrm{MTT}$ solution was added to each well. The plates were further incubated for $4 \mathrm{~h}$ at $37^{\circ} \mathrm{C}$, and the supernatants were discarded after the incubation. Then, the formazan crystals in each well were dissolved in $100 \mu \mathrm{l}$ of DMSO. The amount of purple 
formazan was determined by using a multimode microplate reader (Synergy; BioTek Instruments, Inc.) at $595 \mathrm{~nm}$. All the measurements were carried out in triplicate. The cell viability is presented as the percentage of the control.

Cell proliferation assay. An IncuCyte proliferation assay was used to determine the effect of terrein on human lung cancer cell proliferation. Real-time live-cell imaging was conducted using IncuCyte S3 (Essen BioScience; Sartorius). A549 cells were seeded in 96-well plates at a density of $4 \times 10^{3}$ cells/well and allowed to adhere overnight. Then, the cells were treated with various concentrations $(0-1 \mathrm{mM})$ of terrein, and the plates were placed in the IncuCyte for imaging every $3 \mathrm{~h}$ for 3 days. Proliferation curves were generated using IncuCyte proliferation analysis with confluence as the parameter.

LDH enzyme assay. The cytotoxic effect of terrein on A549 cells was determined using an LDH assay kit, following manufacturer's instructions (G-Biosciences). Briefly, the cells $\left(1 \times 10^{4}\right.$ cells/well) were treated with various concentrations $(0-1 \mathrm{mM})$ of terrein for $24 \mathrm{~h}$. Then, $25 \mu \mathrm{l}$ of supernatant from each sample was transferred to a new 96-well plate, and $25 \mu 1$ reaction mixture was added to each well. After incubation at $37^{\circ} \mathrm{C}$ for $30 \mathrm{~min}, 25 \mu \mathrm{l}$ stop solution was added to each well, and then, the absorbance was measured using a multimode microplate reader (Synergy; BioTek Instruments, Inc.) at $490 \mathrm{~nm}$.

Wound healing assay. The effect of terrein on A549 cell migration was determined by a monolayer wound healing assay. A549 cells were harvested with $0.25 \%$ trypsin containing $1 \mathrm{mM}$ EDTA, plated in 6-well plates at a density of $5 \times 10^{5}$ cells/well in serum-free medium and allowed to adhere overnight. After forming a confluent monolayer, the cells were scratched with a $200-\mu 1$ sterile pipette tip from one side to the other of the wells of the 6-well culture plate. Subsequently, the cells were washed three times with DMEM to remove the cell debris. Then, the cells in each well were immediately given DMEM with or without 20,40 and $80 \mu \mathrm{M}$ terrein. Cell migration was monitored and imaged under a light inverted microscope (Olympus CKX41; Olympus Corporation) using a magnification of $\mathrm{x} 10$ for $0,6,12$ and $24 \mathrm{~h}$. The wound area was measured in three independent wound sites per group and compared with that in the vehicle control group at $0 \mathrm{~h}$. Relative cell motility was calculated as the wound area at 6,12 and $24 \mathrm{~h}$ in at least three independent experiments. The wound areas were quantified using ImageJ software [Java 1.8.0_112 (64_bit); National Institutes of Health].

Transwell migration and invasion assays. The effect of terrein on aggressive A549 cell migration and invasion was assessed using 24-well plate Transwell inserts with polycarbonate membranes with $8-\mu \mathrm{m}$ pores (BD Biosciences). Briefly, the cells were harvested, and $5 \times 10^{4}$ cells were resuspended in $200 \mu \mathrm{l}$ serum-free medium with or without 20,40 and $80 \mu \mathrm{M}$ terrein. The cells were then plated into the Matrigel-coated upper chambers of Transwell inserts for the invasion assay or the noncoated upper chambers of Transwell inserts for the migration assay. In the lower chamber, $750 \mu 1$ medium containing $10 \%$ FBS was used as a chemoattractant to stimulate cell invasion and migration. The plate was incubated at $37^{\circ} \mathrm{C}$ for $24 \mathrm{~h}$. The Transwell insert was separated from the 24-well plate and washed twice with cold PBS. Each sample was fixed with $100 \%$ ice-cold methanol for $20 \mathrm{~min}$ and washed twice with cold PBS. Then, the samples were stained with $0.5 \%$ crystal violet at room temperature for $15 \mathrm{~min}$ and washed with $\mathrm{dH}_{2} \mathrm{O}$ several times until all the excess dye had been removed. The cells that did not invade or migrate from the upper chamber were removed using cotton swabs. The cells that invaded and migrated through the pores of the insert into the lower chamber were photographed under an light inverted microscope at a magnification of $x 10$ and quantified from at least five randomly selected fields by ImageJ software [Java 1.8.0_112 (64_bit)]. The percentage of cell invasion and migration were compared to that in the vehicle control group, which was set to $100 \%$.

Adhesion assay. The effect of terrein on A549 cell adhesion was determined. Briefly, 96-well plates were coated with $50 \mu 1$ of $2.0 \mathrm{mg} / \mathrm{ml}$ Matrigel and incubated at $37^{\circ} \mathrm{C}$ for $2 \mathrm{~h}$. Then, the Matrigel was removed, and cells at a density of $3 \times 10^{4}$ were plated in each well in $100 \mu \mathrm{l}$ of serum-free medium with or without 20,40 and $80 \mu \mathrm{M}$ terrein. After incubation for $30 \mathrm{~min}$ at $37^{\circ} \mathrm{C}$, the nonadherent cells were removed by washing 4 times with $50 \mu \mathrm{l}$ of PBS, and $0.5 \mathrm{mg} / \mathrm{ml}$ MTT solution was added and incubated for $4 \mathrm{~h}$ at $37^{\circ} \mathrm{C}$. The amount of adherent cells was determined by measuring the optical density using a multimode microplate reader at $595 \mathrm{~nm}$. Cell adhesion is expressed as a percentage of that observed in the control group.

Gelatin zymography. A gelatin zymography assay was used to examine the effect of terrein on the activities of proteolytic enzymes released from human lung cancer cells. Briefly, A549 cells were seeded in 6-well plates at a density of $5 \times 10^{5}$ cells/well in DMEM containing 10\% FBS and incubated overnight. The cells were treated with or without 20,40 and $80 \mu \mathrm{M}$ terrein and incubated at $37^{\circ} \mathrm{C}$ for $24 \mathrm{~h}$. After treatment, the supernatants were collected and concentrated using Amicon Ultra- 0.5 Centrifugal Filters 3K (Thermo Fisher Scientific, Inc.). The protein concentration was measured using a Bradford protein assay. Bovine serum albumin (BSA) was used as the standard protein sample. After the calculation of the protein concentration, each sample was adjusted to the same concentration.

The protein samples were separated in $10 \%$ SDS-polyacrylamide gels containing $0.73 \mathrm{mg} / \mathrm{ml}$ gelatin. After electrophoresis, the gels were washed with $1 \mathrm{X}$ renaturing buffer [Novex $^{\mathrm{TM}}$ Zymogram Renaturing Buffer (10X) Invitrogen ${ }^{\mathrm{TM}}$; Thermo Fisher Scientific, Inc.] for $1 \mathrm{~h}$ at room temperature with gentle agitation on a benchtop rocker. The gels were washed 4 times with $\mathrm{ddH}_{2} \mathrm{O}$ for 20 min each and then incubated with $1 \mathrm{X}$ developing buffer [Novex ${ }^{\mathrm{TM}}$ Zymogram Developing Buffer (10X) Invitrogen ${ }^{\mathrm{TM}}$; Thermo Fisher Scientific, Inc.] for $30 \mathrm{~min}$ at room temperature with gentle agitation on a benchtop rocker. Then, the gels were incubated with fresh $1 \mathrm{X}$ developing buffer at $37^{\circ} \mathrm{C}$ overnight. Subsequently, the gels were stained with staining solution (0.5\% Coomassie Brilliant Blue R-250 in methanol:acetic acid:water, 4:1:5, v/v/v) and then washed with destaining solution. Finally, the bands corresponding to matrix metalloproteinase (MMP)-2 (68 kDa) and MMP-9 (82 kDa) were clearly visible in contrast to the blue background and 
were detected by a MiniBIS Pro DNR Bio-Imaging System (BioSciences). The intensities of the bands were quantified by ImageJ software [Java 1.8.0_112 (64_bit)]. The percentages of the MMP-2 and MMP-9 activities are expressed relative to those in the vehicle control group, which was set to $100 \%$.

Reverse transcription-quantitative (RT- $q) P C R$. A549 cells were seeded in a 6 -well plate at a density of $5 \times 10^{5}$ cells/well in DMEM containing 10\% FBS and incubated overnight. The cells were treated with or without 20,40 and $80 \mu \mathrm{M}$ terrein and incubated for $24 \mathrm{~h}$ at $37^{\circ} \mathrm{C}$. Total RNA was isolated using RNeasy Mini Kit following manufacturer's instructions (Qiagen, Inc.) and RNA concentration was measured using NanoDrop spectrophotometer (Thermo Fisher Scientific, Inc.). First strand cDNA was synthesized from $400 \mathrm{ng} / \mu 1 \mathrm{RNA}$ using the Thermo Scientific RevertAid Reverse Transcriptase kit (Thermo Fisher Scientific, Inc.). Quantitative real-time PCR was conducted using a Chromo4 ${ }^{\mathrm{TM}}$ Detection system (Bio-Rad Laboratories, Inc.) according to cycling conditions outlined by the PCR array manufacturer. All genes were detected (listed in the Table I) and analyzed through real-time PCR. PCR cycle was performed with iTaq $^{\mathrm{TM}}$ Universal SYBR Green mixture (Bio-Rad Laboratories, Inc.) using the following cycling conditions: $95^{\circ} \mathrm{C}$ for $2 \mathrm{~min}$, followed by 40 cycles at $95^{\circ} \mathrm{C}$ for $15 \mathrm{sec}, 61^{\circ} \mathrm{C}$ for $15 \mathrm{sec}, 72^{\circ} \mathrm{C}$ for $1 \mathrm{~min}$, and then $72^{\circ} \mathrm{C}$ for $2 \mathrm{~min}$. Data were analyzed using Optical Monitor 3 software (Bio-Rad Laboratories, Inc.) and normalized to GAPDH mRNA expression. Relative gene expression was quantified using the $2^{-\Delta \Delta C q}$ method (31).

$V E G F$ determination. To examine whether terrein could inhibit angiogenic processes, the function of VEGF was evaluated using the VEGF human enzyme-linked immunosorbent assay (ELISA) kit (product code ab100662; Abcam). Briefly, the cells were treated with or without 20,40 and $80 \mu \mathrm{M}$ terrein for $24 \mathrm{~h}$. The supernatants were collected and concentrated using Amicon Ultra-4 Centrifugal Filters 10K (Thermo Fisher Scientific, Inc.). The protein concentrations were measured using a Bradford protein assay, and each sample was adjusted to the same concentration.

For the assay, as aforementioned, an ELISA kit (product code ab100662; Abcam), with an antibody specific for human VEGF was used to coat the wells of the plate prior to adding the standards and protein samples, according to the manufacturer's instructions. Then, the plate was incubated at $4^{\circ} \mathrm{C}$ overnight with gentle shaking. The solution was discarded, and the plate was washed 4 times with $1 \mathrm{X}$ wash solution. Then, $100 \mu 1$ of $1 \mathrm{X}$ biotinylated anti-human VEGF antibody was added to each well and incubated for $1 \mathrm{~h}$ at room temperature. Subsequently, the unbound biotinylated antibody was removed by washing, and $100 \mu \mathrm{l}$ of $1 \mathrm{X}$ HRP-conjugated streptavidin was added to each well and incubated for $45 \mathrm{~min}$ at room temperature. Then, $100 \mu 1$ of TMB substrate solution was added and incubated for $30 \mathrm{~min}$ at room temperature in the dark. The color developed in proportion to the bound VEGF in each sample. The stop solution was added to each well, and the color changed from blue to yellow. The intensity of the color was immediately measured at $450 \mathrm{~nm}$.

Tube formation assay. The tube formation assay is a rapid and quantitative method for examining cell differentiation
Table I. Sequence-specific primers for qPCR.

\begin{tabular}{llc}
\hline Gene name & \multicolumn{1}{c}{ Primer sequence (5'-3') } & $\begin{array}{c}\text { Product } \\
\text { size }\end{array}$ \\
\hline MMP-2 & $\begin{array}{l}\text { F: CTCATCGCAGATGCCTGGAA } \\
\text { R: TTCAGGTAATAGGCACCCTTGAAGA }\end{array}$ & 104 \\
MMP-9 & $\begin{array}{l}\text { F: ATCCGGCACCTCTATGGTC } \\
\text { GAPDH }\end{array}$ & $\begin{array}{l}\text { R: CTGAGGGGTGGACAGTGG } \\
\text { F: ATCTTCTTTTGCGTCGCCAG }\end{array}$ \\
& R: TTCCCCATGGTGTCTGAGC & 51 \\
\hline
\end{tabular}

$F$, forward; $R$, reverse.

and changes in angiogenic processes (32). A 24-well plate was coated with $10 \mathrm{mg} / \mathrm{ml}$ Matrigel and incubated for $1 \mathrm{~h}$ at $37^{\circ} \mathrm{C}$. The remaining liquid was carefully removed from the culture plate without disrupting the layer of Matrigel matrix. Then, $5 \times 10^{4} \mathrm{~A} 549$ cells in $1 \mathrm{ml}$ of serum-free medium with or without 20,40 and $80 \mu \mathrm{M}$ terrein were added to each well and incubated for $24 \mathrm{~h}$ at $37^{\circ} \mathrm{C}$. Tube formation was photographed by inverted microscopy (Olympus CKX41), and the tubular structures in five randomly selected fields were quantified using the Angiogenesis Analyzer plugin for ImageJ software [Java 1.8.0_112 (64_bit)] (33). The percentage of tube length was compared to that in the vehicle control group.

Western blot analysis. A549 cells were seeded in 60-mm culture dishes at a density of $5 \times 10^{5}$ cells/dish in DMEM containing $10 \%$ FBS and incubated overnight. The cells were treated with or without 20, 40 and $80 \mu \mathrm{M}$ terrein and incubated for $24 \mathrm{~h}$ at $37^{\circ} \mathrm{C}$. After treatment, the cells were lysed with RIPA buffer $(5 \mathrm{ml}$ of $1 \mathrm{M}$ Tris- $\mathrm{HCl} \mathrm{pH} 7.4,30 \mathrm{ml}$ of $5 \mathrm{M} \mathrm{NaCl}, 5 \mathrm{ml}$ of $20 \% \mathrm{NP}-40$, $5 \mathrm{ml}$ of $10 \%$ sodium deoxycholate, $0.5 \mathrm{ml}$ of $20 \%$ SDS, $50 \mathrm{ml}$ of $\mathrm{dH}_{2} \mathrm{O}$ and protease inhibitor cocktail) on ice. Subsequently, the cell lysates were centrifuged at $15,000 \mathrm{~g}$ at $4^{\circ} \mathrm{C}$ for $10 \mathrm{~min}$. The protein concentration was measured using a Bradford protein assay. Equal amounts $(50 \mu \mathrm{g})$ of the total protein extracts were separated by $10 \%$ SDS-polyacrylamide gel electrophoresis (SDS-PAGE) and transferred to PVDF membranes. The membranes were blocked with 5\% BSA in TBS-T buffer (5\% w/v BSA, 1 X Tris-buffered saline solution and $0.1 \%$ Tween-20) at room temperature for $1 \mathrm{~h}$ and then incubated with primary antibodies against integrin $\alpha \mathrm{M}(1: 1,000$; cat. no. sc-1186; Santa Cruz Biotechnology, Inc.), total AKT (1:1,000; product no. 9272) , pAKT (Ser473) (1:1,000; product no. 9271), pAKT (Thr308) (1:1,000; product no. 4056), totalFAK (1:1,000; product no. 3285; all from Cell Signaling Technology, Inc.), pFAK (Tyr397) (1:1,000; cat. no. 44-624G; Invitrogen ${ }^{\mathrm{TM}}$; Thermo Fisher Scientific, Inc.), total mTOR (1:1,000; product no. 2972), pmTOR (Ser2448) (1:1,000; product no. 2971), total P70S6 Kinase (1:1,000; product no. 2708), pP70S6 Kinase (Thr389) (1:1,000; product no. 9234), total PI3K p85 (1:1,000; product no. 4292; all from Cell Signaling Technology, Inc.), pPI3K p85 (Tyr458) (1:1,000; cat. no. PA5-17387; Invitrogen ${ }^{\mathrm{TM}}$; Thermo Fisher Scientific, Inc.), total VEGFR2 (1:1,000; product no. 9698), pVEGFR2 (Tyr1175) (1:1,000; product no. 3770), and GAPDH (1:1,000; product no. 2118; all from Cell Signaling Technology, 
Inc.) at $4^{\circ} \mathrm{C}$ overnight. After washing 3 times with TBS-T, the membranes were incubated with horseradish peroxidase-conjugated anti-mouse (1:5,000; product no. 7076) or anti-rabbit IgG antibodies (1:5,000; product no. 7074; both from Cell Signaling Technology, Inc.) for $1 \mathrm{~h}$. The membranes were visualized by enhanced chemiluminescence using ECL plus ${ }^{\mathrm{TM}}$ western blotting detection reagents (Bio-Rad Laboratories) and recorded on gel documentation (UVITE,) or X-ray film. The intensities of the protein bands were quantified by ImageJ software [Java 1.8.0_112 (64_bit)].

Immunofluorescence microscopy. A549 cells were seeded on round micro cover glasses $\left(\mathrm{VWR}^{\circledR}\right)$ in 24 -well plates at a density of $3 \times 10^{3}$ cells/well in DMEM containing $10 \%$ FBS and incubated overnight. The cells were treated with or without 20 , 40 and $80 \mu \mathrm{M}$ terrein for $24 \mathrm{~h}$. The cells were washed three times with $\mathrm{PBS}^{++}$(calcium and magnesium) and fixed with $4 \%$ paraformaldehyde for $20 \mathrm{~min}$ at room temperature. After washing three times with $\mathrm{PBS}^{++}$, the cells were permeabilized with $0.1 \%$ Triton $\mathrm{X}-100$ for $5 \mathrm{~min}$ at room temperature, and then, the permeabilized cells were washed three times with $\mathrm{PBS}^{++}$. The cells were blocked with blocking buffer (3\% BSA in $\mathrm{PBS}^{++}$) for $1 \mathrm{~h}$ at room temperature and then incubated with a pFAK (Tyr397) polyclonal antibody (cat. no. 44-624G; Invitrogen ${ }^{\mathrm{TM}}$; Thermo Fisher Scientific, Inc.) (1:200) at $4^{\circ} \mathrm{C}$ overnight. Then, the cells were incubated with Alexa Fluor 488-conjugated goat anti-rabbit IgG (H+L) (1:800; cat. no. A27034; Life Technologies; Thermo Fisher Scientific, Inc.) and rhodamine phalloidin (1:320; cat. no. R415; Life Technologies; Thermo Fisher Scientific, Inc.) for $1 \mathrm{~h}$ at room temperature. The stained cells were washed three times with $\mathrm{PBS}^{++}$, and then, the cells on glass coverslips were mounted onto microscope slides $\left(\mathrm{VWR}^{\circledR}\right)$ in ProLong Gold Antifade Mountant (Life Technologies; Thermo Fisher Scientific, Inc.) and VECTASHIELD ${ }^{\circledR}$ Mounting Medium with DAPI (Vector Lab) (1:1). The stained cells were observed with a Nikon A1R confocal laser scanning microscope system (Nikon Corporation) with a $60 \mathrm{X}$ objective.

Statistical analysis. All the experiments were performed at least in triplicate in each group. The data are presented as the mean \pm SEM and were analyzed by GraphPad Prism version 5.01 software (GraphPad Software, Inc.). Statistical significance was calculated using ANOVA with Dunnett's multiple comparison post hoc test. $\mathrm{P}<0.05$ was considered to indicate a statistically significant difference.

\section{Results}

Purification of terrein. The fungus Aspergillus terreus CRI301 was cultured in Sabouraud dextrose agar under stationary conditions at room temperature for 34 days. As revealed in Fig. 1A, the increased number of fungi was associated with the days of culture. The culture (3.6 1) of Aspergillus terreus CRI301 was filtered to separate the cells from the broth. The culture broth was extracted three times with an equal volume of EtOAc. The EtOAc layers were combined and evaporated to dryness, yielding $2.535 \mathrm{~g}$ of crude extract. The crude EtOAc extract was purified by Sephadex LH-20 column chromatography and eluted with $\mathrm{MeOH}$ to yield 30 fractions (Fig. 1B). On
Table II. ${ }^{1} \mathrm{H}$ NMR (400 MHz) data of terrein in Acetone-d6.

\begin{tabular}{lc}
\hline & Terrein \\
\cline { 2 - 2 } Position & $\delta_{\mathrm{H}}(\mathrm{ppm})$ \\
\hline 1 & - \\
2 & $5.96(\mathrm{~s})$ \\
3 & - \\
4 & $4.73\left({ }^{1} \mathrm{H}, \mathrm{br} s\right)$ \\
5 & $4.07\left({ }^{1} \mathrm{H}, \mathrm{br} s\right)$ \\
$1^{\prime}$ & $6.43\left({ }^{1} \mathrm{H}, d, J=15.9 \mathrm{~Hz}\right)$ \\
$2^{\prime}$ & $6.82\left({ }^{1} \mathrm{H}, m\right)$ \\
$3^{\prime}$ & $1.90\left({ }^{3} \mathrm{H}, d, J=15.9 \mathrm{~Hz}\right)$
\end{tabular}

the basis of their TLC characteristics, similar fractions were combined to yield 10 fractions (Fig. 1C-E). Fraction 4 was obtained as a pale yellow powder that was crystallized from dichloromethane $\left(\mathrm{CH}_{2} \mathrm{Cl}_{2}\right)$ and contained terrein $(258.7 \mathrm{mg})$ in the form of white needles. The structure of terrein was characterized by ${ }^{1} \mathrm{H}$ NMR spectroscopy and finally confirmed by comparison with data in the literature (Fig. 1F). Terrein was obtained in the form of white needles. The ${ }^{1} \mathrm{H}$ NMR spectrum of terrein (Fig. 1G) exhibited three methylene protons at $\delta_{\mathrm{H}}$ $6.82\left({ }^{1} \mathrm{H}, m, \mathrm{H}-2^{\prime}\right), 6.43\left({ }^{1} \mathrm{H}, d, J=15.9 \mathrm{~Hz}, \mathrm{H}-1^{\prime}\right)$ and $5.96\left({ }^{1} \mathrm{H}\right.$, $s, \mathrm{H}-2)$, two oxygenated methine protons at $\delta_{\mathrm{H}} 4.73\left({ }^{1} \mathrm{H}, \mathrm{s}, \mathrm{H}-4\right)$ and $4.07\left({ }^{1} \mathrm{H}, \mathrm{s}, \mathrm{H}-5\right)$ and a methyl group at $\delta_{\mathrm{H}} 1.90\left({ }^{3} \mathrm{H}, d, J=\right.$ $\left.15.9 \mathrm{~Hz}, \mathrm{H}-3^{\prime}\right)$, as revealed in Table II.

Cytotoxic effects of terrein on the viability and proliferation of lung cancer cells. First, the cytotoxic effects of terrein on different cell lines were examined, including A549 lung cancer cells, African green monkey kidney (Vero) cells, L6 skeletal muscle cells and H9C2 cardiomyoblast cells, using an MTT assay. All the cell lines were treated with various concentrations of terrein for $24 \mathrm{~h}$, and the maximum final concentration of DMSO $(0.1 \%)$ was used as the vehicle control. The results demonstrated that terrein significantly inhibited the viability of A549 cells, Vero cells, L6 cells and H9C2 cells with $\mathrm{IC}_{50}$ values of 229, 870, 1,240 and $579 \mu \mathrm{M}$, respectively (Fig. 2A-D). Terrein exhibited more toxicity in lung cancer cells than in all the representative normal cells. Moreover, the selective index (SI) of terrein on A549 cells compared with that of terrein on all the normal cell lines was calculated using the following equation: $\mathrm{SI}=\mathrm{IC}_{50}$ of normal cells/IC $\mathrm{IC}_{50}$ of $\mathrm{A} 549$ cells. As a result, the SI values of terrein on A549 cells were 3.8, 5.4 and 2.5 compared to Vero cells, L6 cells and H9C2 cells, respectively, indicating that terrein has high cytotoxic selectivity against cancer cells compared with normal cells. In addition, LDH assays were performed to confirm the damaging effect of terrein. The LDH enzyme is normally used as a biomarker of cellular cytotoxicity and cytolysis, as it is released from damaged cells (34). As revealed in Fig. 2E, 50-1,000 $\mu \mathrm{M}$ terrein significantly induced cytotoxicity in A549 cells.

It was also determined whether these cytotoxic effects of terrein interfered with the process of cell proliferation using the IncuCyte assay. Cells were treated with different concentrations of terrein $(1-1,000 \mu \mathrm{M})$. Cell proliferation 
A

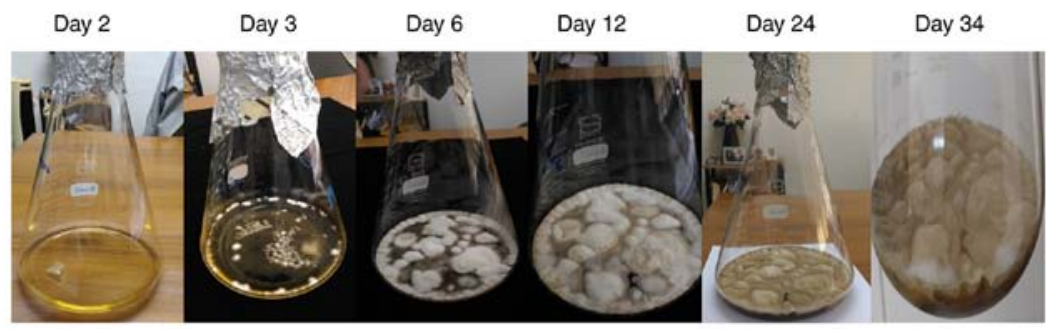

B

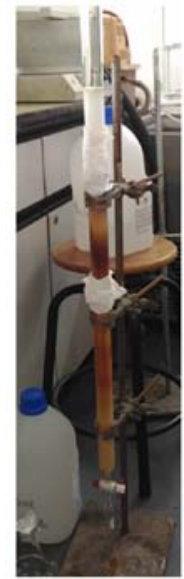

C

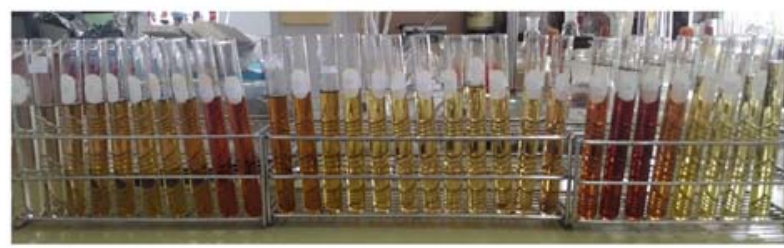

D

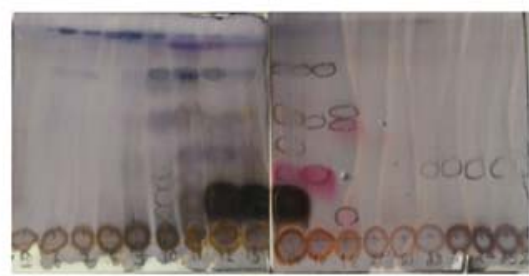

E

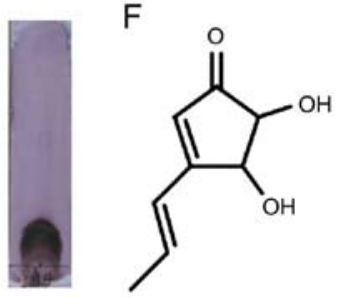

G
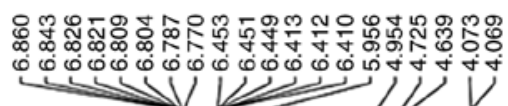

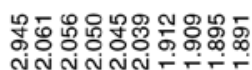
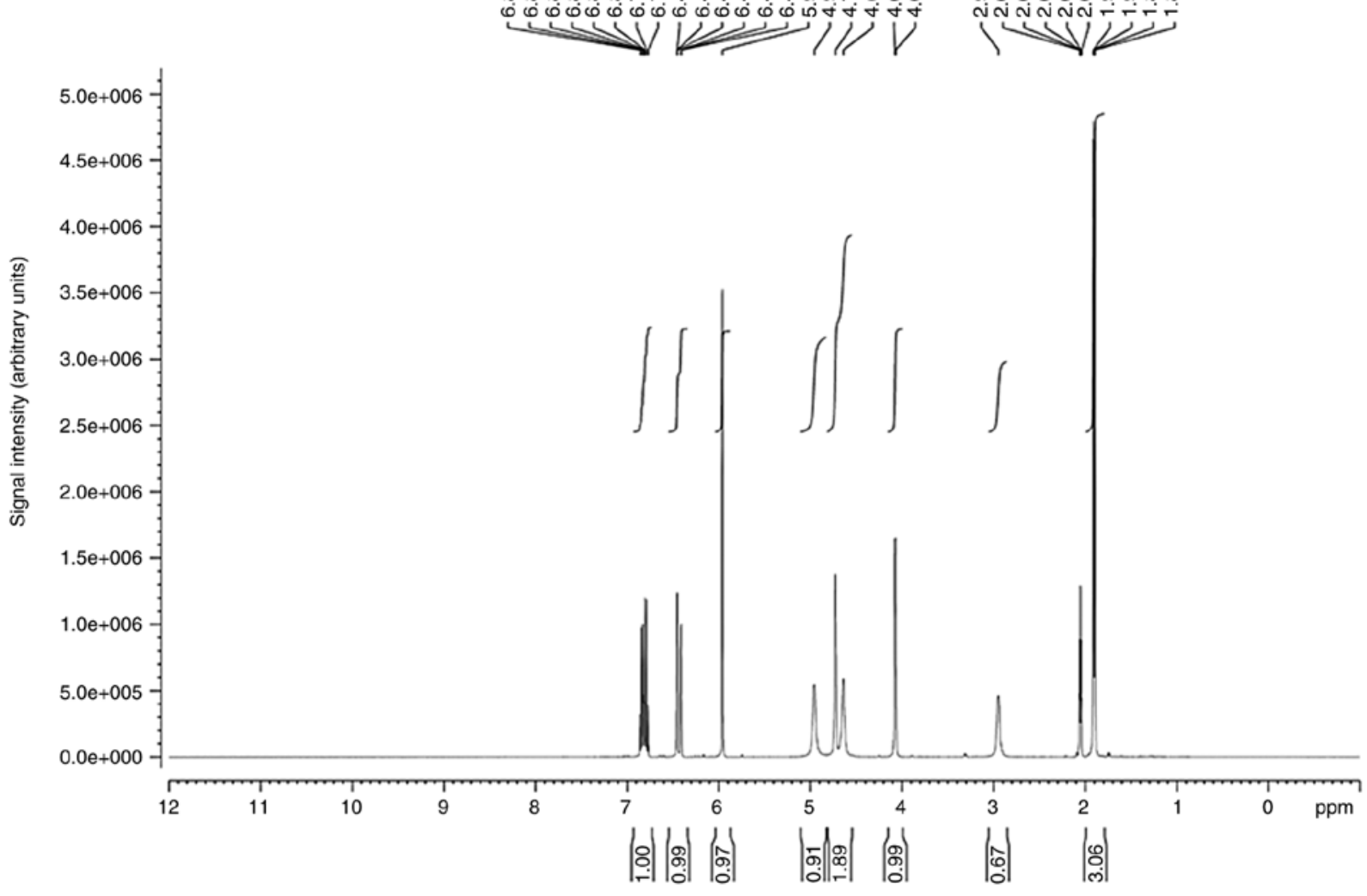

Chemical shift (ppm)

Figure 1. Characteristics of terrein. (A) Aspergillus terreus was cultured for 34 days. (B) Separation of the pure compound using Sephadex LH-20 column chromatography. (C) All fractions were collected. (D and E) Thin layer chromatography. (F) The structure of terrein was characterized by ${ }^{1} \mathrm{H}$ NMR spectroscopic data. (G) The 1H NMR spectrum of terrein.

was monitored every $3 \mathrm{~h}$ for 3 days. Proliferation curves were generated using IncuCyte proliferation analysis with cell confluence as the parameter. The results revealed that 20-1,000 $\mu \mathrm{M}$ terrein exhibited dose-dependent inhibitory effects on A549 cell proliferation, as revealed in Fig. 2F. The present results indicated that a high concentration of terrein inhibited A549 cell viability and proliferation by damaging the cells. Thus, to further investigate the effects of terrein on 
A

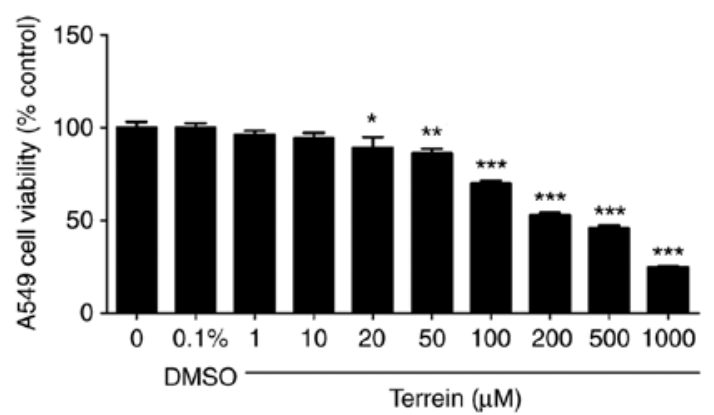

C

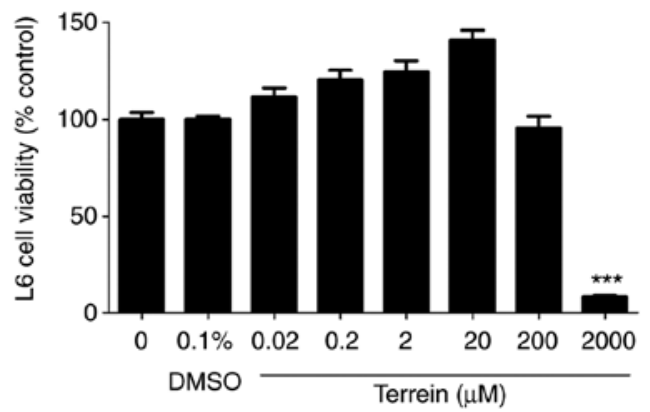

B

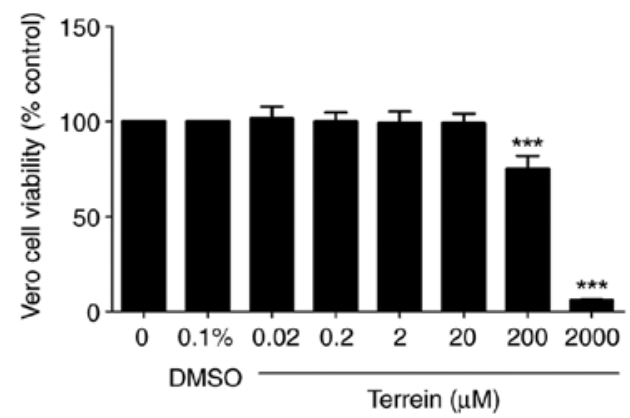

D

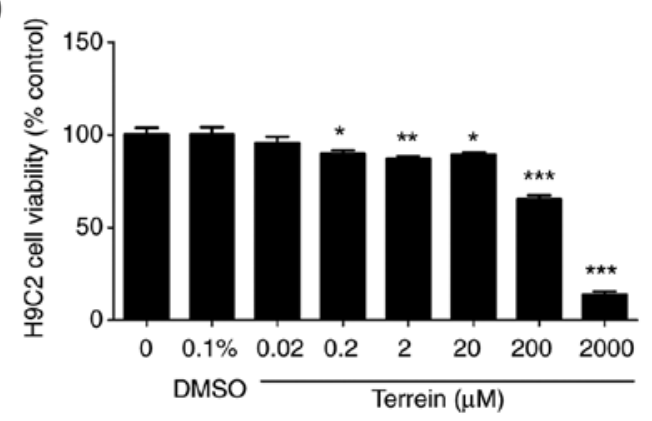

E
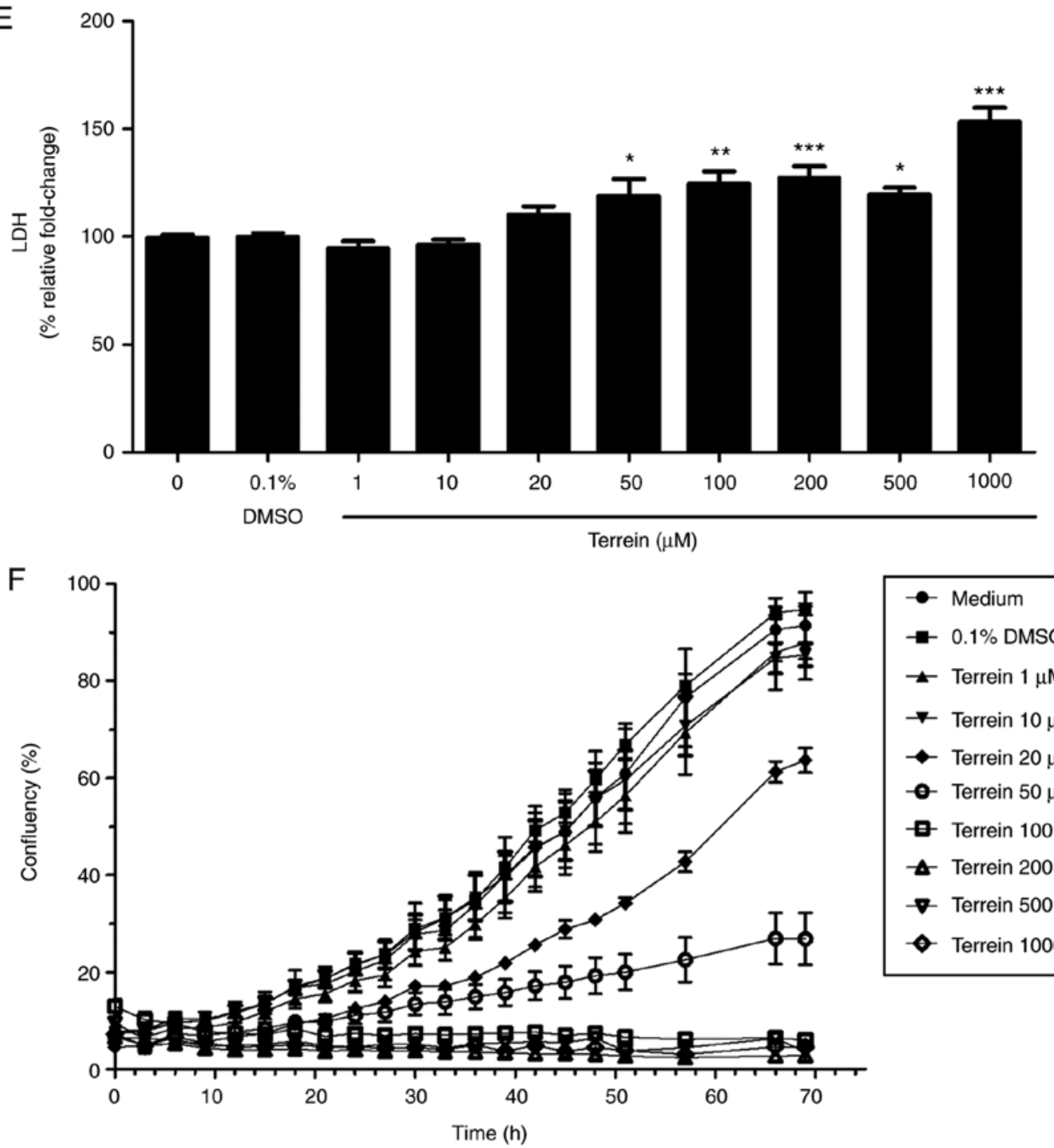

- Medium

- $0.1 \%$ DMSO

$\leftarrow$ Terrein $1 \mu \mathrm{M}$

$\rightarrow$ Terrein $10 \mu \mathrm{M}$

$\leadsto$ Terrein $20 \mu \mathrm{M}$

-0- Terrein $50 \mu \mathrm{M}$

E. Terrein $100 \mu \mathrm{M}$

- $\mathbf{A}$ Terrein $200 \mu \mathrm{M}$

$\boldsymbol{\nabla}$ Terrein $500 \mu \mathrm{M}$

- Terrein $1000 \mu \mathrm{M}$

Figure 2. Terrein inhibits cell viability and proliferation in lung cancer cells. Cell viability was assessed by MTT assay, in which various concentrations of terrein were treated for $24 \mathrm{~h}$. (A) A549 cells (B) Vero cells (C) L6 cells (D) H9C2 cells (E) LDH assay and (F) proliferation assay. Values are expressed as the mean \pm SEM of three independent experiments. ${ }^{*} \mathrm{P}<0.05,{ }^{* *} \mathrm{P}<0.01$ and ${ }^{* * *} \mathrm{P}<0.001$, compared with the vehicle control $(0.1 \% \mathrm{DMSO})$. LDH, lactate dehydrogenase. 


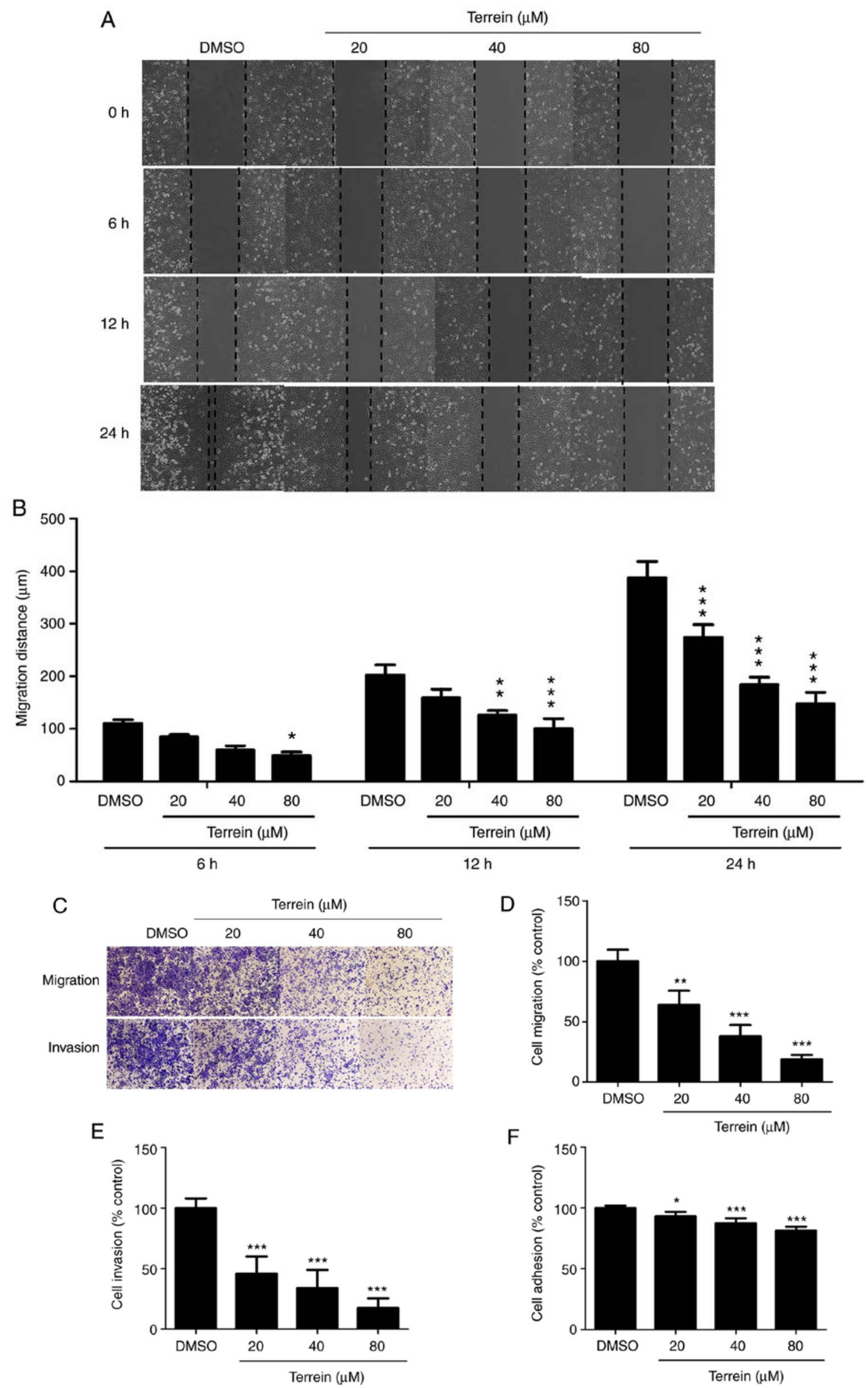

Figure 3. Continued. 

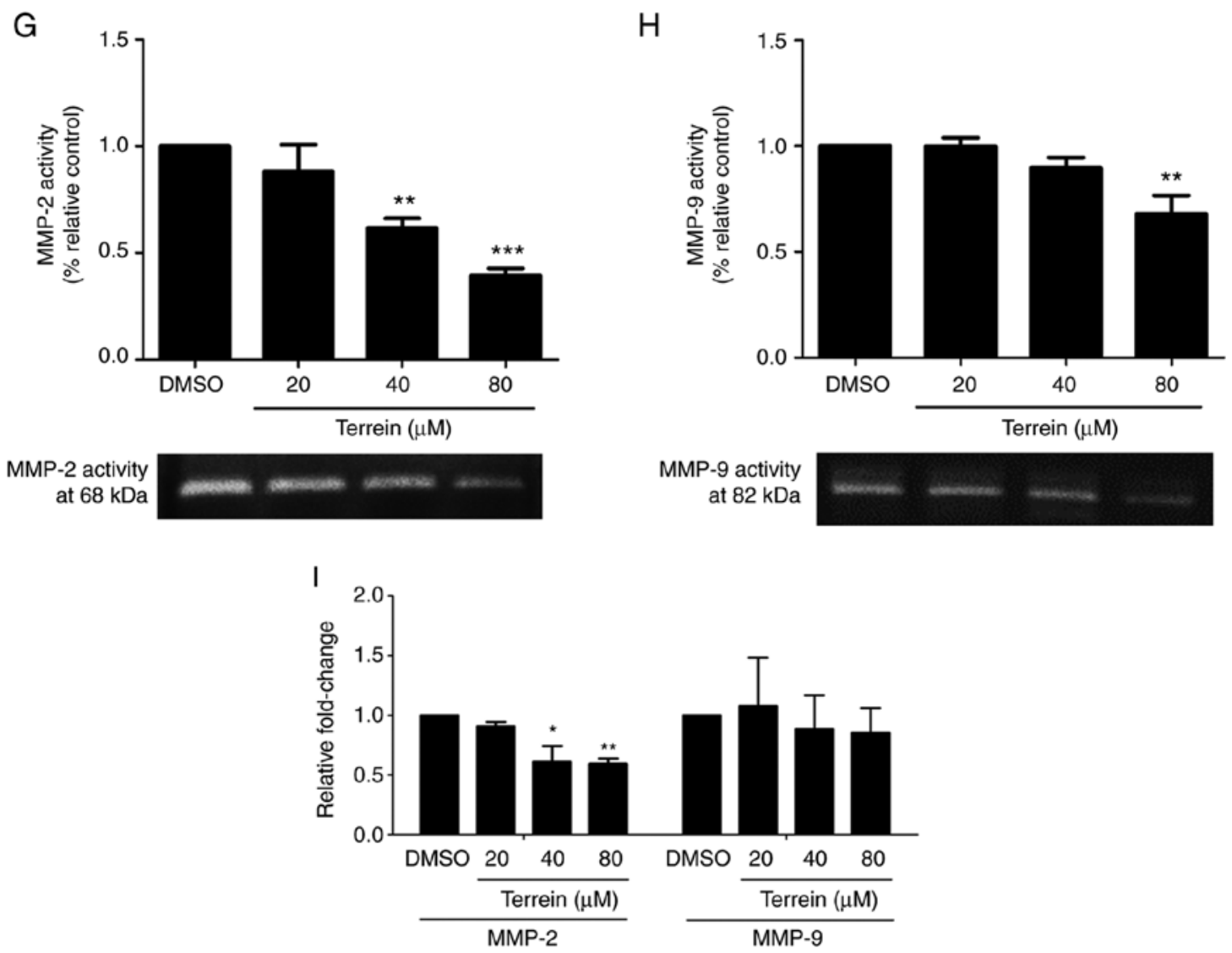

Figure 3. Effect of terrein on A549 cell metastatic processes. Wound healing assay was performed to assess the migration of A549 cells after 0,6, 12 and $24 \mathrm{~h}$ of terrein treatment. (A) A representative image of the scratch-wound healing assay of A549 cells using a magnification of x10. (B) Migration distance of the treated and untreated samples were measured in at least three independent locations in each wound. (C) Effects of terrein on A549 lung cancer cell migration and invasion after $24 \mathrm{~h}$ of terrein treatment and crystal violet staining. Representative images were captured at a magnification of x10. (D) The migrated and (E) invasive cells were quantified by using ImageJ software. (F) Adhesion of A549 cells on Matrigel-coated plates. Effect of terrein on cell adherence were measured by MTT assay after 30 min of terrein incubation. (G) Representative gelatin zymography of MMP-2 after $24 \mathrm{~h}$ of terrein treatment. (H) Representative gelatin zymography of MMP-9 after $24 \mathrm{~h}$ of terrein treatment. The activity of MMP-2 and MMP-9 were quantified by ImageJ. (I) Expression of MMP-2 and MMP-9 was determined using qPCR after $24 \mathrm{~h}$ of terrein treatment. Significance was measured as the mean \pm SEM of at least three separate experiments. ${ }^{*} \mathrm{P}<0.05,{ }^{* * *} \mathrm{P}<0.01$ and ${ }^{* * *} \mathrm{P}<0.001$, compared with the vehicle control. MMP, matrix metalloproteinase.

metastatic processes, the concentrations of 20,40 and $80 \mu \mathrm{M}$ terrein, which exhibit low levels of toxicity in cells, were selected.

Terrein inhibits metastatic processes of A549 lung cancer cells. To determine the effect of terrein on the metastatic processes of lung cancer cells, its inhibitory effect on lung cancer cell migration was first evaluated. The migration of cells was measured using a wound healing assay. In this method, the concentrations of terrein that exhibited low toxicity (20, 40 and $80 \mu \mathrm{M}$ ) were used to treat A549 cells for 0, 6, 12 and $24 \mathrm{~h}$. The results revealed that terrein significantly inhibited cell migration at 6, 12 and $24 \mathrm{~h}$ (Fig. $3 \mathrm{~A}$ and B).

The ability of terrein to suppress the migration and invasion of A549 lung cancer cells was further examined. A549 cells were treated with or without 20,40 and $80 \mu \mathrm{M}$ terrein for $24 \mathrm{~h}$, and a Transwell assay was used to observe the effect of terrein on A549 cell migration and invasion. The results revealed that terrein significantly decreased the number of migrated and invasive cells by as much as 78 and $82 \%$, respectively, compared with the vehicle control (Fig. 3C-E). The effect of terrein on the adhesion process, since it is associated with the early step of metastasis (35), was also determined. As revealed in Fig. 3F, the highest concentration of terrein decreased A549 cell adhesion by approximately $19 \%$ compared with the vehicle control.

To assess the effect of terrein on the process of cell invasion, the effect of terrein on the activities and expression of MMP-2 and MMP-9 was determined using gelatin zymography and qPCR, respectively. A549 lung cancer cells were treated with 20, 40 and $80 \mu \mathrm{M}$ terrein for $24 \mathrm{~h}$. The results revealed that terrein significantly suppressed the gelatinase activities of both MMP-2 and MMP-9. Bands corresponding to MMP-2 (68 kDa) and MMP-9 (82 kDa) were clearly observed, and 40 and $80 \mu \mathrm{M}$ terrein significantly inhibited MMP-2 and $80 \mu \mathrm{M}$ terrein significantly inhibited MMP-9, as revealed in Fig. 3G and $H$, respectively. In addition, terrein significantly inhibited MMP-2 expression and tended to inhibit MMP-9 expression as revealed in the Fig. 3I. These data suggested that terrein had the ability to inhibit the metastatic processes of lung cancer cells.

Terrein inhibits the angiogenesis process of A549 lung cancer cells. To examine whether terrein could inhibit the angiogenesis process, A549 cells were treated with or without 20, 40 and $80 \mu \mathrm{M}$ terrein for $24 \mathrm{~h}$. The VEGF-A that was 

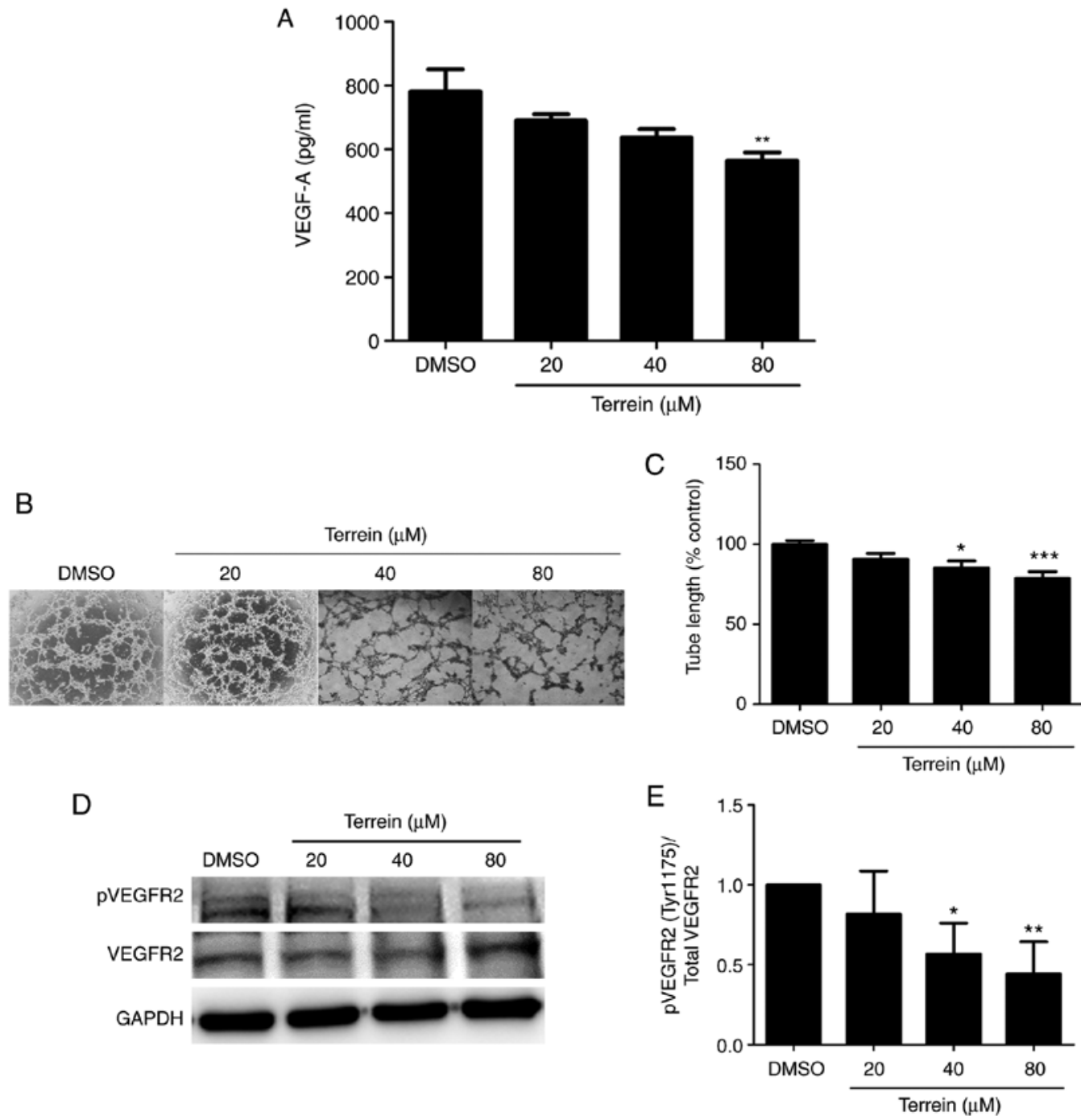

Figure 4. Terrein inhibits the angiogenesis process of A549 lung cancer cells. (A) Effects of terrein on release of VEGF-A from A549 lung cancer cells that was examined by VEGF-A Human ELISA assays after $24 \mathrm{~h}$ of terrein treatment. (B) Terrein inhibited A549 lung cancer cell tube formation. After $24 \mathrm{~h}$ of terrein treatment, tubular structures were captured under an inverted microscope at a magnification of x10. (C) Quantification graph by Angiogenesis Analyzer plugin for ImageJ software. (D) Representation of the protein level of VEGFR2 was measured by western blotting after $24 \mathrm{~h}$ of terrein treatment. (E) Quantification graph of western blotting by ImageJ software. Significance was measured as the mean \pm SEM of at least three separate experiments. ${ }^{*} \mathrm{P}<0.05,{ }^{* * *} \mathrm{P}<0.01$ and ${ }_{* * *} \mathrm{P}<0.001$ compared with the vehicle control. VEGF, vascular endothelial growth factor; VEGF-A, VEGF subtype A; VEGFR2, VEGF receptor tyrosine kinase type 2; p, phosphorylated.

secreted by the A549 cells into the medium was collected, concentrated and detected by human VEGF-A ELISAs. The results revealed that terrein significantly reduced the secretion of VEGF-A from A549 lung cancer cells compared with the vehicle control (Fig. 4A). To further confirm this inhibitory effect, an in vitro capillary-like tube formation assay was performed. This is a rapid and quantitative method for examining cell differentiation and changes associated with the angiogenesis process. To perform the experiment, A549 cells were cultured in Matrigel-coated plates and then treated with or without 20,40 and $80 \mu \mathrm{M}$ terrein for $24 \mathrm{~h}$. Tube formation or the characteristics of A549 cells that formed vessel-like channels were captured by inverted microscopy. As revealed in Fig. 4B and C, terrein significantly suppressed the formation of tube-like structures compared with the vehicle control. The inhibition of VEGFR2 phosphorylation at Tyr1175, which is a crucial site for the migration of cells during angiogenesis, was also detected (Fig. 4D and E).
Terrein inhibits the activity of metastasis mediators in A549 lung cancer cells. To investigate the effect of terrein on the expression of metastasis mediators, such as integrin $\alpha \mathrm{M}, \mathrm{FAK}$, mTORC1, PI3K, AKT and P70S6K, western blotting was performed. A549 cells were treated with different concentrations of terrein for $24 \mathrm{~h}$. As revealed in Fig. 5A-C, the results indicated that terrein significantly inhibited integrin $\alpha \mathrm{M}$ expression and FAK phosphorylation at Tyr397 compared with the vehicle control. Notably, a low concentration of terrein clearly inhibited the phosphorylation of FAK. Active integrins recruit various proteins, including FAK, to FAs to stimulate cell signaling. When FAK is activated, it further stimulates the expression and activation of downstream proteins. The signaling proteins downstream of FAK are PI3K, AKT, mTORC1 and P70S6K. These proteins affect cell survival, proliferation, angiogenesis, invasion, migration and metastasis. The inhibition of FAK leads to the suppression of these downstream signaling mediators (36). The phosphorylation of 
A

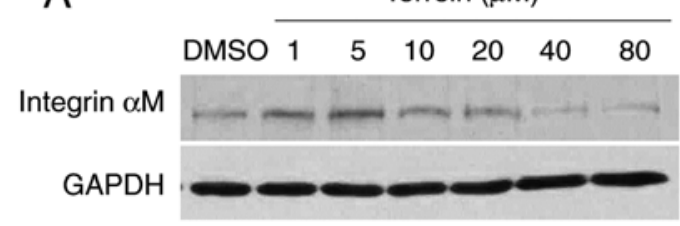

B

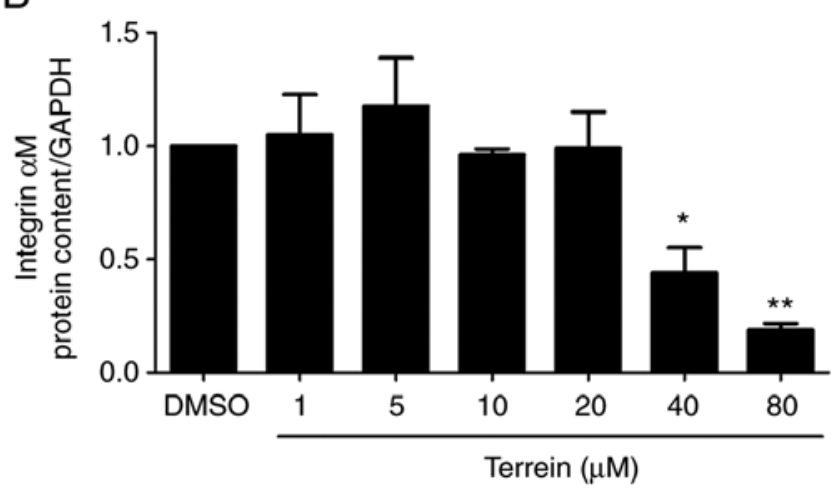

D

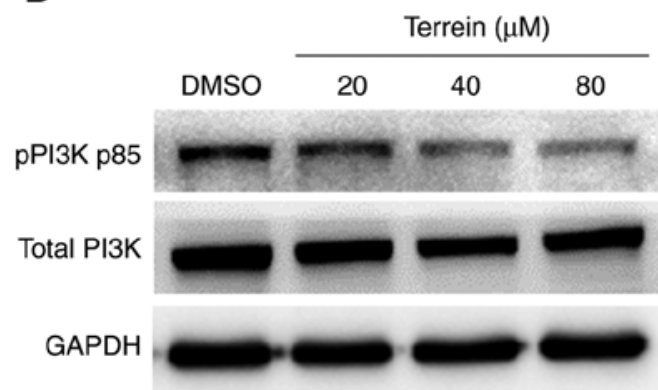

F

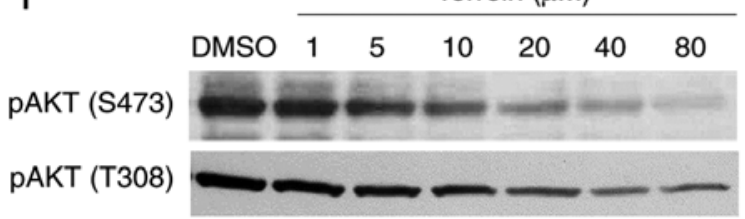

Total AKT

GAPDH

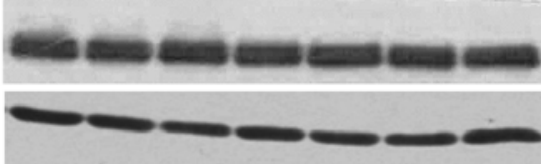

$\mathrm{H}$

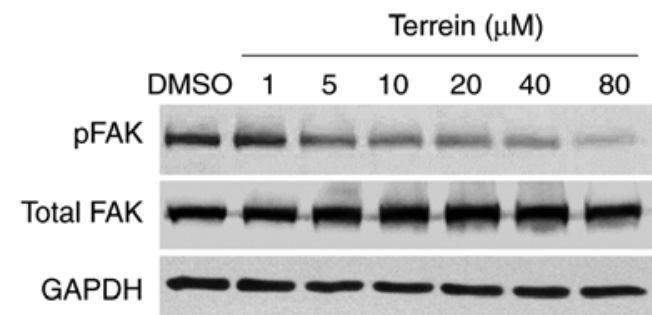

C

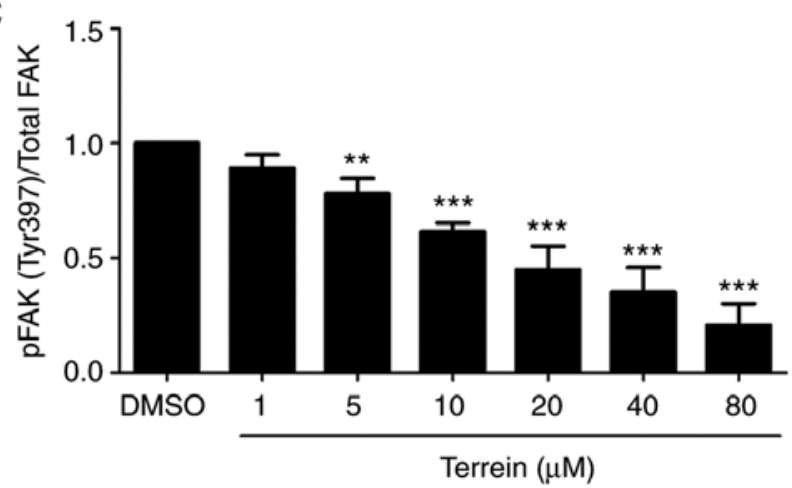

E

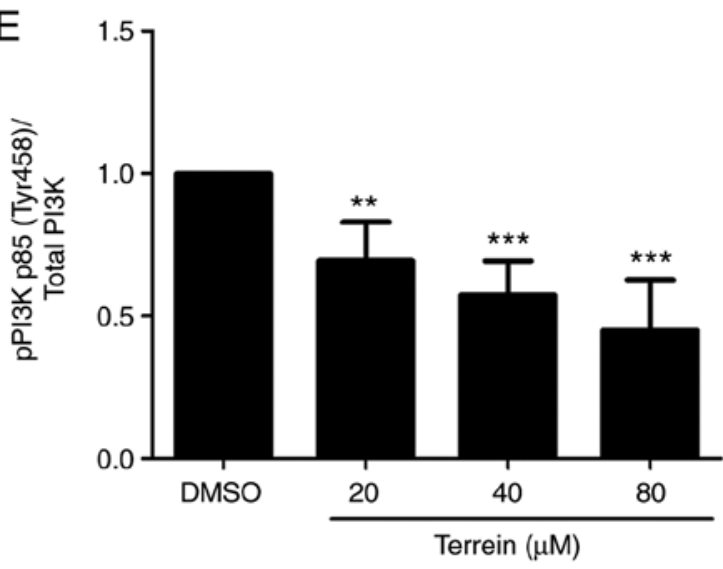

G

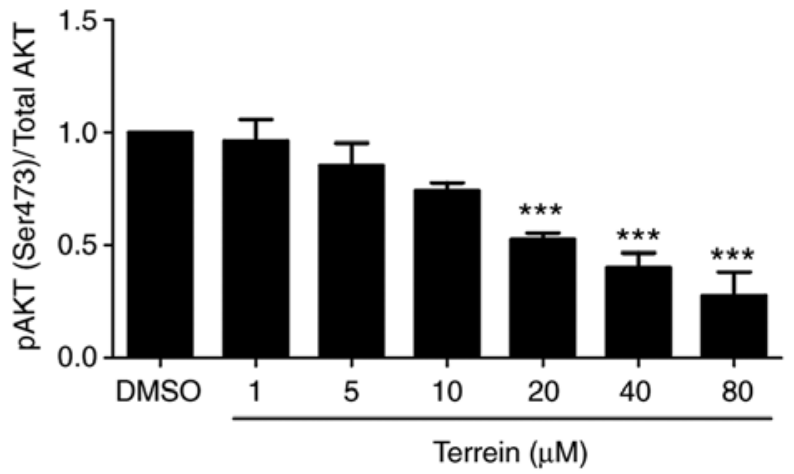

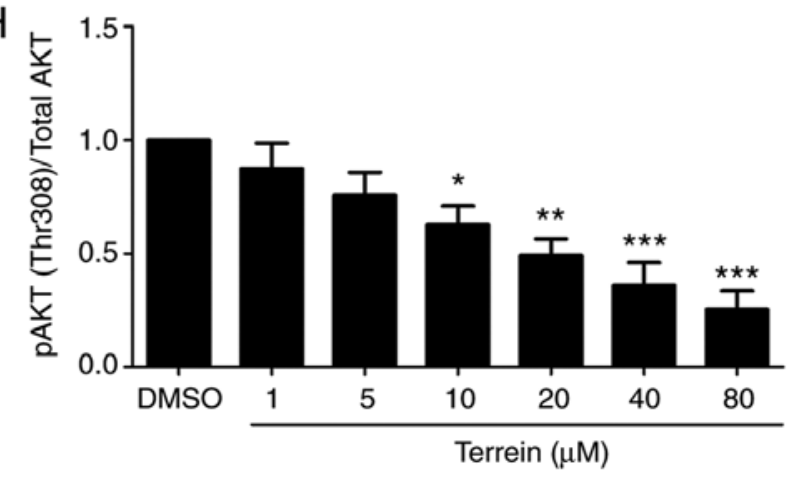

Figure 5. Continued. 

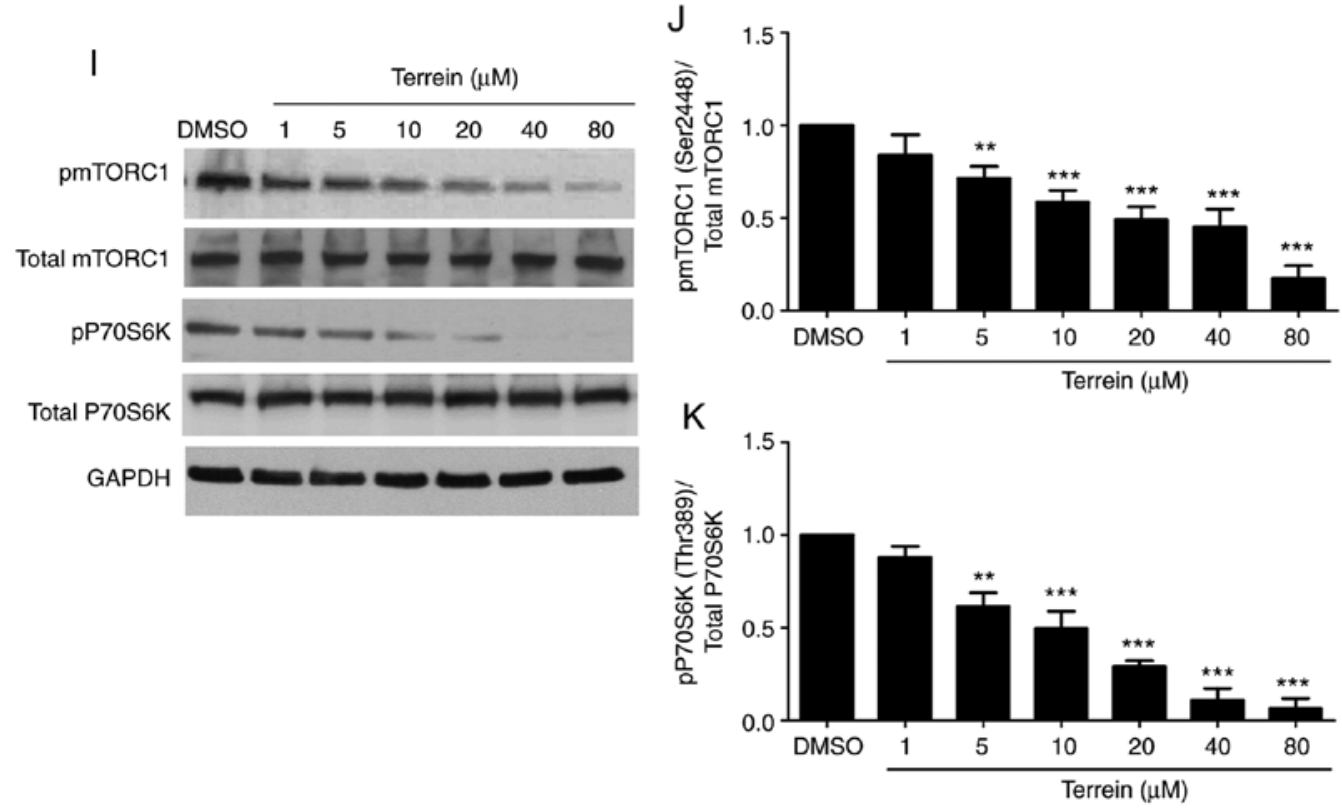

Figure 5. Effects of terrein on the expression of signaling mediators associated with metastatic processes in A549 lung cancer cells. Representative protein levels were examined by western blotting after $24 \mathrm{~h}$ of terrein treatment and the quantified bar graphs are presented. (A-C) Integrin $\alpha \mathrm{M}$ and FAK phosphorylation. (D and E) PI3K p85 phosphorylation. (F-H) AKT phosphorylation. (I) mTORC1 and P70S6K as determined by western blotting. (J) mTORC1 phosphorylation and (K) P70S6K phosphorylation. Significance was measured as the mean \pm SEM of at least three separate experiments. ${ }^{*} \mathrm{P}<0.05$, ${ }^{* *} \mathrm{P}<0.01$ and ${ }^{* * * *} \mathrm{P}<0.001$, compared with the vehicle control. FAK, focal adhesion kinase; PI3K, phosphatidylinositol 3-kinase; AKT, protein kinase-B; mTOR, mammalian target of rapamycin; P70S6K, ribosomal p70S6 kinase; p, phosphorylated.

PI3K p85 at Tyr458 (Fig. 5D and E), AKT at Ser473 (Fig. 5F and G), AKT at Thr308 (Fig. 5F and H), mTORC1 at Ser2448 (Fig. 5I and J) and pP70S6K at Thr389 (Fig. 5I and K) was decreased by terrein in a dose-dependent manner compared with the vehicle control. Therefore, the inhibition of these proteins by terrein resulted in the suppression of metastatic and angiogenic processes in lung cancer cells.

Terrein inhibits the phosphorylation of FAK in A549 lung cancer cells. Immunofluorescence was used to further confirm the effect of terrein on the phosphorylation of FAK at Tyr397 in A549 cells. The representative and quantitative images (Fig. 6) revealed that 40 and $80 \mu \mathrm{M}$ terrein significantly suppressed the phosphorylation of FAK at Tyr397 compared with the vehicle control. Combining these results with the western blot data clearly indicated that terrein had the ability to inhibit the phosphorylation of FAK at Tyr397, and FAK was revealed to be an upstream regulator of numerous proteins involved in cancer metastasis.

\section{Discussion}

Human lung cancer is the leading cause of cancer-related deaths worldwide (1). Most often, lung cancer is diagnosed at metastatic stages, and at these stages, cancer cells have spread to nearby tissues or other parts of the body (2). Therefore, the suppression of metastasis is required to reduce the premature death of cancer patients. Currently, the world has turned its attention to the use natural substances for cancer treatment because they typically have fewer side effects. Terrein is a bioactive natural substance that has been reported to exert various biological effects, including anti-inflammation, melanogenesis inhibition and anticancer effects (20-22). However, to the best of our knowledge, the effect of terrein on the molecular mechanisms that regulate human lung cancer metastasis has not been examined.

In the present study, the effects of terrein on metastatic processes, including cell proliferation, adhesion, migration, invasion and angiogenesis, were investigated using A549 human lung cancer cells. The present results revealed that terrein exhibited cytotoxic effects on different cell types, including A549 cells, Vero cells, L6 cells and H9C2 cells, by inhibiting cell viability with $\mathrm{IC}_{50}$ values of $229,870,1,240$ and $579 \mu \mathrm{M}$, respectively. These results suggest that terrein has a specific effect on A549 lung cancer cells relative to normal cells with a relatively high selectivity index value. As revealed in other studies, terrein exhibited a cytotoxic effect on human cervical cancer cells (HeLa) with an $\mathrm{IC}_{50}$ value of $290 \mu \mathrm{M}(22)$ and on the human breast cancer cell lines MCF-7 and MDA-MB-231 with $\mathrm{IC}_{50}$ values of 2,340 and $700 \mu \mathrm{M}$, respectively (28). $\mathrm{LDH}$ assays were used to measure cell viability (34) and further verified this conclusion. Overall, these data indicated that terrein was more toxic to A549 lung cancer cells than to other types of cancer cells.

Cancer metastasis includes several steps, including cell proliferation, adhesion, migration, invasion and angiogenesis. To determine the effects of terrein on these processes, low concentrations of terrein $(20,40$ and $80 \mu \mathrm{M})$ that were not toxic to the normal cell lines tested were selected. It was first observed that a terrein concentration as low as $20 \mu \mathrm{M}$ started to reduce the proliferative ability of A549 cells. The antimetastatic properties of terrein were observed upon analysis of MMP activity. Numerous studies have demonstrated that MMPs play important roles in tumor progression, invasion, metastasis and angiogenesis $(37,38)$. Increased expression of MMPs has been revealed 
A

DAPI $\quad$ PFAK

F-actin

$3 D$
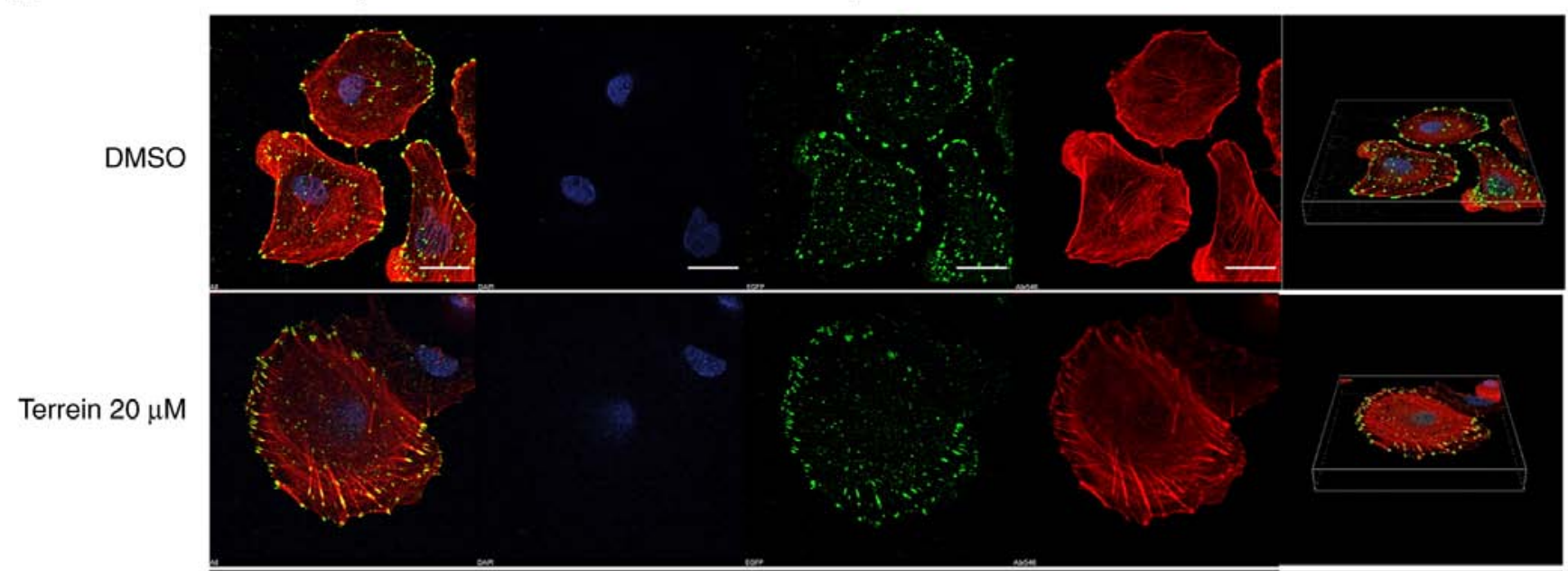

Terrein $40 \mu \mathrm{M}$

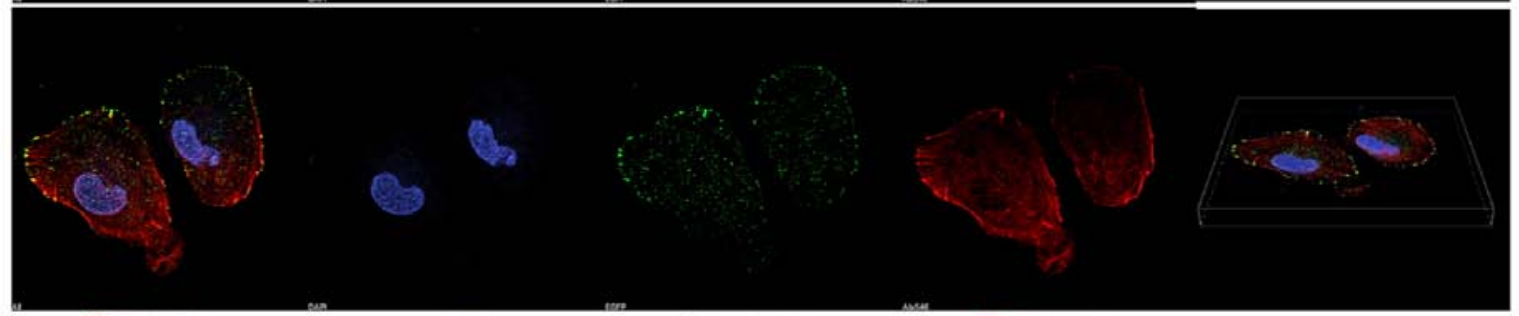

Terrein $80 \mu \mathrm{M}$
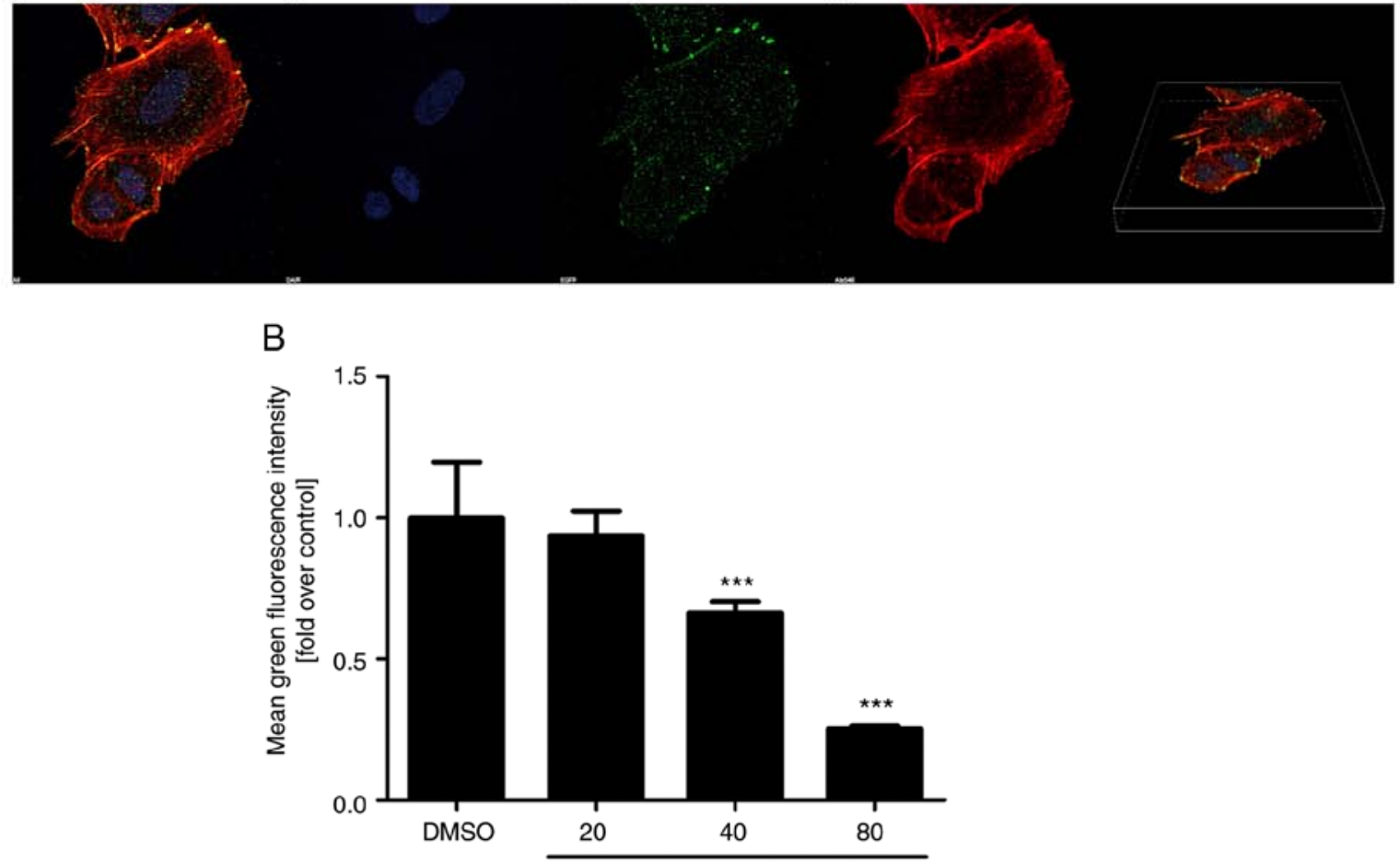

Terrein $(\mu \mathrm{M})$

Figure 6. Effects of terrein on phosphorylation of FAK at Tyr397 in A549 cells. Cells were treated with terrein at 20, 40 and $80 \mu \mathrm{M}$ for $24 \mathrm{~h}$. (A) Representative confocal images of phosphorylation of FAK at Tyr397. (B) Its quantification. Significance was measured as the mean \pm SEM of at least three separate experiments. ${ }^{* * *} \mathrm{P}<0.001$, compared with the vehicle control. Scale bar, $20 \mu \mathrm{m}$. FAK, focal adhesion kinase.

to be associated with poor prognosis in several types of tumors, including breast cancer, gastric cancer and osteosarcoma (39-41). All invasive malignant tumors, including lung cancer cells, are known to express high levels of MMPs, especially MMP-2 and MMP-9 (42). MMP-2 plays an essential role in the progression of cancer because it cleaves several ECM components and basement membranes (43); thus, the development of potential MMP-2 inhibitors has become an important goal in lung cancer therapy. The expression and activity of MMP-9 are increased in NSCLC and are associated with the pathological type and clinical stage of NSCLC (44). The expression levels of MMP-9 were higher in advanced stage III and IV tumors than in primary stage I and II tumors of NSCLC patients, and MMP-9 expression was higher in NSCLC patients with metastasis than in NSCLC patients 
without metastasis and a reduced 5-year survival rate (45). Both MMP-2 and MMP-9 are classified as soluble enzymes that are secreted into the extracellular milieu. Therefore, blocking the activities of these enzymes has the potential to suppress lung cancer cell metastasis and increase the possibility of NSCLC patient survival. In the present study, it was revealed that terrein significantly suppressed both the activities and expression of MMP-2 and MMP-9. These findings indicated that terrein has the potential to act as an antimetastatic agent, which, to the best of our knowledge, to date, has never been reported.

Angiogenesis, or the creation of new blood vessels, is another important mechanism during cancer progression. New blood vessels support the growth of tumors by specifically feeding their hypoxic and necrotic areas to provide essential nutrients and oxygen (46). In the present study, the effect of terrein on angiogenesis was investigated by determining the expression of VEGF-A as a surrogate biomarker. VEGF is a major chemotactic factor during angiogenesis that initiates the migration and adhesion of cells, interactions between endothelial cells and ECM, and formation of a tubular network (47). In mammals, there are several types of VEGF, including VEGF-A, VEGF-B, VEGF-C, and VEGF-D; however, VEGF-A is widely studied and plays a major role in angiogenesis by acting through VEGFR2 (12). It was observed that $80 \mu \mathrm{M}$ terrein significantly attenuated VEGF-A expression. Consistently, the ratio of phosphorylated VEGF-A/VEGFR2 was decreased by terrein compared to the vehicle control, thus indicating that the downstream signaling events induced by the addition of VEGF to the cell medium were inhibited. Furthermore, the effect of terrein on angiogenesis was investigated by examining the in vitro capillary-like tube formation of A549 cells. The characteristics of tube-like structures were reduced by terrein in a dose-dependent manner. These results suggest that terrein suppresses processes known to be involved in angiogenesis.

Thus, our collective dataset suggests that terrein can suppress multiple steps of cancer metastatic processes, including proliferation, wound healing, adhesion, migration and invasion. A more detailed mechanistic analyses was next conducted based on the rationale that focal adhesion complexes are known to be crucial nodes of signaling events that mediate cancer metastasis (48). Notably, the interaction of multiple proteins at focal adhesions is critical to promote the protrusion of the cell membrane leading edge, resulting in the development of invadopodia and lamellipodia (49). At focal adhesions, signal transduction is initiated by interactions of integrins with the ECM, which further promote the assembly of cytoplasmic scaffolds and the recruitment of kinase proteins (50). FAK, or focal adhesion kinase, is one of the principal integrin signaling regulators that is recruited to the site of adhesion, and FAK is autophosphorylated at the Tyr397 site. The autophosphorylation of FAK contributes to the further activation of its intrinsic kinase activity and creates docking sites for several downstream signaling molecules (51). FAK expression is increased in numerous highly malignant human cancers (52). Overexpression of FAK in cancer cells leads to resistance to the apoptotic process (53). In addition, an increase in FAK was revealed to contribute to the activation of the PI3K/AKT and MEK-ERK1/2 signaling pathways, resulting in increased cancer cell survival and proliferation (54). Therefore, to inhibit integrin signaling, the regulation of FAK expression and

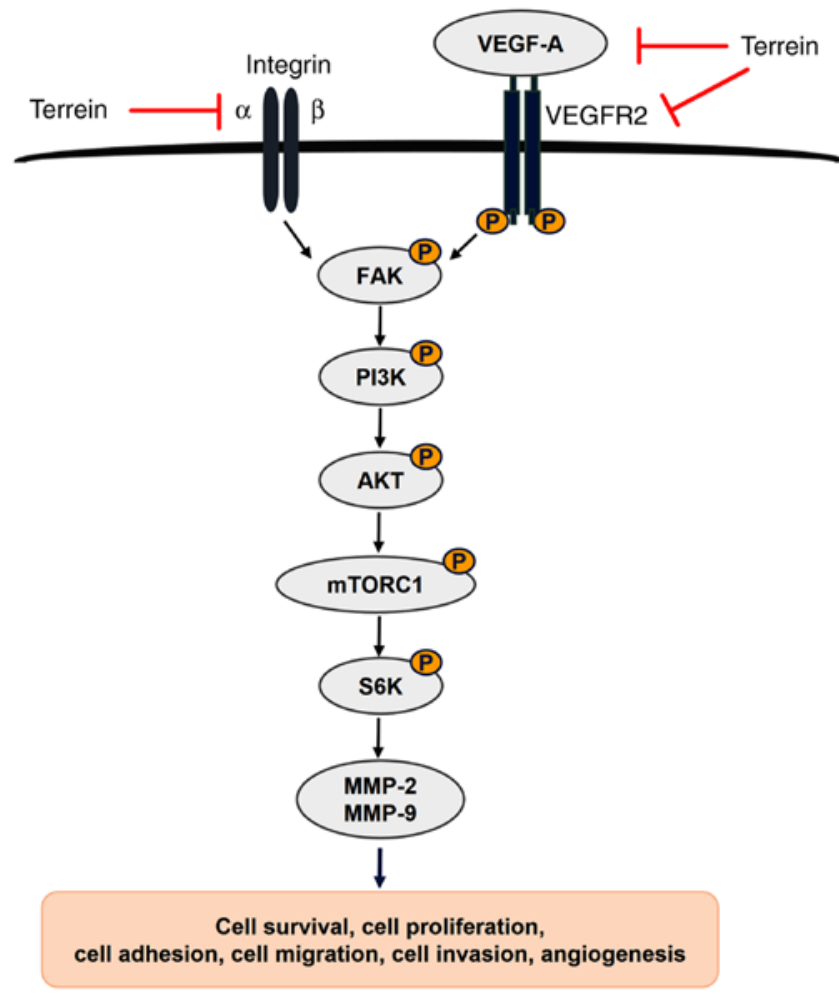

Figure 7. Summary of terrein effects on lung cancer cell metastasis and angiogenesis signaling pathways.

phosphorylation is a well-established goal for the development of effective pharmaceutical antimetastatic agents. As revealed in the present study, terrein could inhibit the expression of integrin $\alpha \mathrm{M}$ and the phosphorylation of FAK at Tyr397, as demonstrated by western blot and immunofluorescence analyses. The present results revealed that terrein could reduce stress fiber formation. Normally, cell migration is associated with adhesion and actin cytoskeleton organization, which also involves a series of lamellipodia extension and actin polymerization. In addition, initial adhesions are formed through the engagement of integrin receptors by the ECM (55). The integrin-FAK signaling pathway is known to be associated with cell adhesion and migration, and these effects are regulated by downstream molecules. Inhibition of FAK leads to retraction of filopodia and lamellipodia in cell protrusions, resulting in stress fiber formation in retractile cell bodies (6). The present results suggested that the inhibition of FAK reduced the adhesion of cells to the ECM, which contributed to reduced cell migration.

Next, mediators downstream of FAK, including PI3K, AKT, mTOR and P70S6K, were further investigated. The signaling pathway of PI3K/AKT is well recognized to associate with multiple cellular processes such as cell proliferation, differentiation and motility (56). In addition, mTOR is one important downstream target of the PI3K/AKT signaling involved with cell movement and metastasis (57). The protein mTORC1 induces protein synthesis and cell growth by phosphorylating S6K1 and 4E-BP1 (58), while mTORC2 regulates the organization of the actin cytoskeleton through F-actin stress fibers, paxillin, RhoA, Rac1, Cdc42 and PKC $\alpha$ (59). The inhibition of the PI3K/AKT/mTOR pathway by an mTOR inhibitor has 
been demonstrated to suppress cancer cell invasion and migration and promote apoptosis in tumors $(60,61)$. Recent research has demonstrated that inhibiting the FAK/PI3K/AKT/mTOR pathway and reducing MMP-2 and MMP-9 protein expression suppressed gastric cancer cell migration and invasion (62). Furthermore, the PI3K/AKT/mTOR pathway plays a pivotal role in regulating angiogenesis, increasing hypoxia-inducible factor $1 \alpha(\mathrm{HIF}-1 \alpha)$ translation and promoting VEGF production (63). The results of the present study revealed that terrein significantly decreased the phosphorylation of PI3K p85 at Tyr458, AKT at Ser473 and Thr308, mTORC1 at Ser2448 and pP70S6K at Thr389. Therefore, all these data indicated that terrein has the ability to suppress the PI3K/AKT/mTOR/S6K1 pathway and thus affects cancer cell proliferation, survival, migration, invasion, metastasis and angiogenesis, as revealed in Fig. 7.

In conclusion, the present study demonstrated the novel finding that terrein acted as an anticancer agent in lung cancer. This occured via numerous effects, such as the inhibition of proliferation and metastatic processes, including adhesion, migration and invasion. Mechanistically, terrein regulated the integrin/FAK interaction and its downstream signaling pathway, PI3K/AKT/mTOR/S6K1. In addition, terrein could inhibit angiogenic processes by decreasing VEGF secretion and tube formation by reducing the VEGF-A/VEGFR2 interaction. All these data suggested that terrein is a potential new compound that is worthy of further development as an anticancer agent. Further experiments to assess the effect of terrein in vivo are further suggested.

\section{Acknowledgments}

We would like to thank Ms Vu Hong Loan Nguyen, Department of Biology, York University, for sharing her laboratory techniques for the IncuCyte assay.

\section{Funding}

This work was supported by research grants from the Faculty of Medicine (grant nos. 140/2560 and 209/2562), Graduate School and The Strategic Wisdom and Research Institute, Srinakharinwirot University, Thailand, National Research Council of Thailand: NRCT (2562) and Canada-ASEAN Scholarships and Educational Exchanges for Development (2019-2020). Work in the GS lab was funded by the National Science and Engineering Research Council (NSERC), Canadian Institutes of Health Research (CIHR) and a Career Investigator Award from the Heart and Stroke Foundation.

\section{Availability of data and materials}

The datasets used and/or analyzed during the present study are available from the corresponding author upon reasonable request.

\section{Authors' contributions}

PB performed the experiments and data analysis and was the main author of the manuscript. WT and GS supervised the experiments and revised the manuscript for important intellectual content. MNA provided the materials needed for the preparation of terrein and validated the data analysis. HKS performed the immunofluorescence experiment and interpreted the data. CP participated in the experimental design and provided the reagents needed for the IncuCyte assay. All the authors read and approved the final version of the manuscript.

\section{Ethics approval and consent to participate}

Not applicable.

\section{Patient consent for publication}

Not applicable.

\section{Competing interests}

The authors declare that they have no competing interests.

\section{References}

1. Bray F, Ferlay J, Soerjomataram I, Siegel RL, Torre LA and Jemal A: Global cancer statistics 2018: GLOBOCAN estimates of incidence and mortality worldwide for 36 cancers in 185 countries. CA Cancer J Clin 68: 394-424, 2018.

2. Qi HW, Xin LY, Xu X, Ji XX and Fan LH: Epithelial-tomesenchymal transition markers to predict response of Berberine in suppressing lung cancer invasion and metastasis. J Transl Med 12: 22, 2014.

3. Leber MF and Efferth T: Molecular principles of cancer invasion and metastasis (Review). Int J Oncol 34: 881-895, 2009.

4. Hamidi $\mathrm{H}$ and Ivaska J: Every step of the way: Integrins in cancer progression and metastasis. Nat Rev Cancer 18: 533-548, 2018.

5. Maziveyi M and Alahari SK: Cell matrix adhesions in cancer: The proteins that form the glue. Oncotarget 8: 48471-48487, 2017.

6. Yu H, Gao M, Ma Y, Wang L, Shen Y and Liu X: Inhibition of cell migration by focal adhesion kinase: Time-dependent difference in integrin-induced signaling between endothelial and hepatoblastoma cells. Int J Mol Med 41: 2573-2588, 2018.

7. Mitra SK, Hanson DA and Schlaepfer DD: Focal adhesion kinase: In command and control of cell motility. Nat Rev Mol Cell Biol 6: 56-68, 2005.

8. Khan KH, Yap TA, Yan L and Cunningham D: Targeting the PI3K-AKT-mTOR signaling network in cancer. Chin J Cancer 32: 253-265, 2013.

9. Liu L, Li F, Cardelli JA, Martin KA, Blenis J and Huang S: Rapamycin inhibits cell motility by suppression of mTOR-mediated S6K1 and 4E-BP1 pathways. Oncogene 25: 7029-7040, 2006.

10. Fingar DC, Richardson CJ, Tee AR, Cheatham L, Tsou C and Blenis J: mTOR controls cell cycle progression through its cell growth effectors S6K1 and 4E-BP1/eukaryotic translation initiation factor 4E. Mol Cell Biol 24: 200-216, 2004.

11. Olsson AK, Dimberg A, Kreuger J and Claesson-Welsh L: VEGF receptor signalling - in control of vascular function. Nat Rev Mol Cell Biol 7: 359-371, 2006.

12. Dimova I, Popivanov G and Djonov V: Angiogenesis in cancer-general pathways and their therapeutic implications. J buon 19: 15-21, 2014.

13. Rydén L, Linderholm B, Nielsen NH, Emdin S, Jönsson PE and Landberg G: Tumor specific VEGF-A and VEGFR2/KDR protein are co-expressed in breast cancer. Breast Cancer Res Treat 82: 147-154, 2003.

14. Tanno S, Ohsaki Y, Nakanishi K, Toyoshima E and Kikuchi K: Human small cell lung cancer cells express functional VEGF receptors, VEGFR-2 and VEGFR-3. Lung Cancer 46: 11-19, 2004.

15. Hamerlik P, Lathia JD, Rasmussen R, Wu Q, Bartkova J, Lee M, Moudry P, Bartek J Jr, Fischer W, Lukas J, et al: Autocrine VEGF-VEGFR2-Neuropilin-1 signaling promotes glioma stem-like cell viability and tumor growth. J Exp Med 209: 507-520, 2012.

16. Zhu X and Zhou W: The emerging regulation of VEGFR-2 in triple-negative breast cancer. Front Endocrinol (Lausanne) 6: 159,2015 . 
17. Le Boeuf F, Houle F and Huot J: Regulation of vascular endothelial growth factor receptor 2-mediated phosphorylation of focal adhesion kinase by heat shock protein 90 and Src kinase activities. J Biol Chem 279: 39175-39185, 2004.

18. Koch S, Tugues S, Li X, Gualandi L and Claesson-Welsh L: Signal transduction by vascular endothelial growth factor receptors. Biochem J 437: 169-183, 2011.

19. Raistrick H and Smith G: Studies in the biochemistry of microorganisms: The metabolic products of Aspergillus terreus Thom. a new mould metabolic product-terrein. Biochem J 29: 606-611, 1935.

20. Lee JC, Yu MK, Lee R, Lee YH, Jeon JG, Lee MH, Jhee EC, Yoo ID and Yi HK: Terrein reduces pulpal inflammation in human dental pulp cells. J Endod 34: 433-437, 2008.

21. Park SH, Kim DS, Kim WG, Ryoo IJ, Lee DH, Huh CH, Youn SW Yoo ID and Park KC: Terrein: A new melanogenesis inhibitor and its mechanism. Cell Mol Life Sci 61: 2878-2885, 2004.

22. Porameesanaporn Y, Uthaisang-Tanechpongtamb W, Jarintanan F, Jongrungruangchok S and Wongsatayanon B: Terrein induces apoptosis in HeLa human cervical carcinoma cells through p53 and ERK regulation. Oncol Rep 29: 1600-1608, 2013.

23. Zhang F, Mijiti M, Ding W, Song J, Yin Y, Sun W and Li Z-Y: (+)-Terrein inhibits human hepatoma Bel-7402 proliferation through cell cycle arrest. Oncol Rep 33: 1191-1200, 2015.

24. Chen YF, Wang SY, Shen H, Yao XF, Zhang FL and Lai D: The marine-derived fungal metabolite, terrein, inhibits cell proliferation and induces cell cycle arrest in human ovarian cancer cells. Int J Mol Med 34: 1591-1598, 2014.

25. Liao WY, Shen CN, Lin LH, Yang YL, Han HY, Chen JW, Kuo SC, Wu SH and Liaw CC: Asperjinone, a nor-neolignan, and terrein, a suppressor of ABCG2-expressing breast cancer cells, from thermophilic Aspergillus terreus. J Nat Prod 75: 630-635, 2012.

26. Shibata A, Ibaragi S, Mandai H, Tsumura T, Kishimoto K, Okui T, Hassan NM, Shimo T, Omori K, Hu GF, et al: Synthetic terrein inhibits progression of head and neck cancer by suppressing angiogenin production. Anticancer Res 36: 2161-2168, 2016.

27. Arakawa M, Someno T, Kawada M and Ikeda D: A new terrein glucoside, a novel inhibitor of angiogenin secretion in tumor angiogenesis. J Antibiot (Tokyo) 61: 442-448, 2008.

28. Kasorn A, Loison F, Kangsamaksin T, Jongrungruangchok S and Ponglikitmongkol M: Terrein inhibits migration of human breast cancer cells via inhibition of the Rho and Rac signaling pathways. Oncol Rep 39: 1378-1386, 2018.

29. Jahng JWS, Alsaadi RM, Palanivel R, Song E, Hipolito VEB, Sung HK, Botelho RJ, Russell RC and Sweeney G: Iron overload inhibits late stage autophagic flux leading to insulin resistance. EMBO Rep 20: e47911, 2019.

30. Sung HK, Song E, Jahng JWS, Pantopoulos K and Sweeney G: Iron induces insulin resistance in cardiomyocytes via regulation of oxidative stress. Sci Rep 9: 4668, 2019.

31. Livak KJ and Schmittgen TD: Analysis of relative gene expression data using real-time quantitative PCR and the 2(-Delta Delta C(T)) method. Methods 25: 402-408, 2001

32. Lee $\mathrm{H}$ and Kang KT: Advanced tube formation assay using human endothelial colony forming cells for in vitro evaluation of angiogenesis. Korean J Physiol Pharmacol 22: 705-712, 2018.

33. Carpentier G, Berndt S, Ferratge S, Rasband W, Cuendet M, Uzan G and Albanese P: Angiogenesis analyzer for ImageJ - A comparative morphometric analysis of "endothelial tube formation assay' and 'fibrin bead assay'. Sci Rep 10: 11568, 2020.

34. Kumar P, Nagarajan A and Uchil PD: Analysis of cell viability by the lactate dehydrogenase assay. Cold Spring Harb Protoc 2018, 2018.

35. Bendas $G$ and Borsig L: Cancer cell adhesion and metastasis Selectins, integrins, and the inhibitory potential of heparins. Int J Cell Biol 2012: 676731, 2012.

36. Ata $\mathrm{R}$ and Antonescu CN: Integrins and cell metabolism: An intimate relationship impacting cancer. Int J Mol Sci 18: 189, 2017

37. McCawley LJ and Matrisian LM: Matrix metalloproteinases: Multifunctional contributors to tumor progression. Mol Med Today 6: 149-156, 2000 .

38. Stetler-Stevenson WG: The role of matrix metalloproteinases in tumor invasion, metastasis, and angiogenesis. Surg Oncol Clin N Am 10: 383-392, 2001.

39. Li H, Zhang K, Liu LH, Ouyang Y, Bu J, Guo HB and Xiao T: A systematic review of matrix metalloproteinase 9 as a biomarker of survival in patients with osteosarcoma. Tumour Biol 35: 5487-5491, 2014

40. Uchibori M, Nishida Y, Nagasaka T, Yamada Y, Nakanishi K and Ishiguro $\mathrm{N}$ : Increased expression of membrane-type matrix metalloproteinase-1 is correlated with poor prognosis in patients with osteosarcoma. Int J Oncol 28: 33-42, 2006.
41. Shen W, Xi H, Wei B and Chen L: The prognostic role of matrix metalloproteinase 2 in gastric cancer: A systematic review with meta-analysis. J Cancer Res Clin Oncol 140: 1003-1009, 2014.

42. Guo CB, Wang S, Deng C, Zhang DL, Wang FL and Jin XQ: Relationship between matrix metalloproteinase 2 and lung cancer progression. Mol Diagn Ther 11: 183-192, 2007.

43. Houghton AM: Matrix metalloproteinases in destructive lung disease. Matrix Biol 44-46: 167-174, 2015.

44. El-Badrawy MK, Yousef AM, Shaalan D and Elsamanoudy AZ: Matrix metalloproteinase-9 expression in lung cancer patients and its relation to serum mmp-9 activity, pathologic type, and prognosis. J Bronchology Interv Pulmonol 21: 327-334, 2014.

45. Zheng S, Chang Y, Hodges KB, Sun Y, Ma X, Xue Y, Williamson SR, Lopez-Beltran A, Montironi R and Cheng L: Expression of KISS1 and MMP-9 in non-small cell lung cancer and their relations to metastasis and survival. Anticancer Res 30: 713-718, 2010.

46. Bergers $\mathrm{G}$ and Benjamin LE: Tumorigenesis and the angiogenic switch. Nat Rev Cancer 3: 401-410, 2003.

47. Niu $\mathrm{G}$ and Chen $\mathrm{X}$ : Vascular endothelial growth factor as an anti-angiogenic target for cancer therapy. Curr Drug Targets 11: 1000-1017, 2010

48. Mirza AA, Kahle MP, Ameka M, Campbell EM and Cuevas BD: MEKK2 regulates focal adhesion stability and motility in invasive breast cancer cells. Biochim Biophys Acta Mol Cell Res 1843: 945-954, 2014.

49. Machesky LM: Lamellipodia and filopodia in metastasis and invasion. FEBS Lett 582: 2102-2111, 2008.

50. Aoudjit $\mathrm{F}$ and Vuori $\mathrm{K}$ : Integrin signaling in cancer cell survival and chemoresistance. Chemother Res Pract 2012: 283181, 2012.

51. Frame MC, Patel H, Serrels B, Lietha D and Eck MJ: The FERM domain: Organizing the structure and function of FAK. Nat Rev Mol Cell Biol 11: 802-814, 2010.

52. Cance WG, Harris JE, Iacocca MV, Roche E, Yang X, Chang J, Simkins S and Xu L: Immunohistochemical analyses of focal adhesion kinase expression in benign and malignant human breast and colon tissues: Correlation with preinvasive and invasive phenotypes. Clin Cancer Res 6: 2417-2423, 2000.

53. Tai YL, Chen LC and Shen TL: Emerging roles of focal adhesion kinase in cancer. Biomed Res Int 2015: 690690, 2015.

54. Bouchard V, Demers M-J, Thibodeau S, Laquerre V, Fujita N, Tsuruo T, Beaulieu J-F, Gauthier R, Vézina A, Villeneuve L and Vachon PH: Fak/Src signaling in human intestinal epithelial cell survival and anoikis: Differentiation state-specific uncoupling with the PI3-K/Akt-1 and MEK/Erk pathways. J Cell Physiol 212: 717-728, 2007.

55. Burridge $\mathrm{K}$ and Guilluy C: Focal adhesions, stress fibers and mechanical tension. Exp Cell Res 343: 14-20, 2016.

56. Jiang N, Dai Q, Su X, Fu J, Feng X and Peng J: Role of PI3K/AKT pathway in cancer: The framework of malignant behavior. Mol Biol Rep 47: 4587-4629, 2020.

57. Brader S and Eccles SA: Phosphoinositide 3-kinase signalling pathways in tumor progression, invasion and angiogenesis. Tumori 90: 2-8, 2004.

58. Dowling RJO, Topisirovic I, Fonseca BD and Sonenberg N: Dissecting the role of mTOR: Lessons from mTOR inhibitors. Biochim Biophys Acta 1804: 433-439, 2010.

59. Zhou $\mathrm{H}$ and Huang S: Role of mTOR signaling in tumor cell motility, invasion and metastasis. Curr Protein Pept Sci 12: 30-42, 2011.

60. Vivanco I and Sawyers CL: The phosphatidylinositol 3-Kinase AKT pathway in human cancer. Nat Rev Cancer 2: 489-501, 2002.

61. Shih YW, Chen PS, Wu CH, Jeng YF and Wang CJ: Alpha-chaconine-reduced metastasis involves a PI3K/Akt signaling pathway with downregulation of NF-kappaB in human lung adenocarcinoma A549 cells. J Agric Food Chem 55: 11035-11043, 2007

62. Wu YJ, Lin SH, Din ZH, Su JH and Liu CI: Sinulariolide inhibits gastric cancer cell migration and invasion through downregulation of the EMT process and suppression of FAK/PI3K/AKT/mTOR and MAPKs signaling pathways. Mar Drugs 17: 668, 2019.

63. Karar J and Maity A: PI3K/AKT/mTOR pathway in angiogenesis. Front Mol Neurosci 4: 51, 2011.

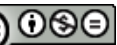

This work is licensed under a Creative Commons Attribution-NonCommercial-NoDerivatives 4.0 International (CC BY-NC-ND 4.0) License. 